\title{
Intestinal parasitic infection alters bacterial gut microbiota in children
}

\author{
Miguel A. Toro-Londono ${ }^{1}{ }^{\text {, }}$, Katherine Bedoya-Urrego ${ }^{1,2}$ ， Gisela M. Garcia-Montoya ${ }^{2}$, Ana L. Galvan-Diaz ${ }^{3}$, \\ Juan F. Alzate ${ }^{\text {Corresp. } 1,2}$ \\ ${ }^{1}$ Centro Nacional de Secuenciación Genómica - CNSG, Universidad de Antioquia, medellin, antioquia, Colombia \\ 2 Parasitology group, School of Medicine, Universidad de Antioquia, medellin, antioquia, Colombia \\ 3 Environmental Microbiology Group, School of Microbiology, Universidad de Antioquia, medellin, antioquia, Colombia \\ Corresponding Author: Juan F. Alzate \\ Email address: jfernando.alzate@udea.edu.co
}

The study of the burden that parasites can exert upon the bacterial gut microbiota was restricted by the available technologies and their costs. Currently, next-generation sequencing coupled with traditional methodologies allows the study of eukaryotic parasites (protozoa and helminths) and its effects on the human bacterial gut microbiota diversity. This diversity can be altered by a variety of factors such as age, diet, genetics and parasitic infections among others. The disturbances of the gut microbiota have been associated with a variety of illnesses. Children population in developing countries, are especially susceptible to parasitic infections because of the lack of proper sanitation and undernutrition, allowing both, the thriving of intestinal parasites and profound alteration of the gut microbiota. In this work, we have sampled the stool of 23 children from 4 different children's care-centers in Medellin, Colombia, and we have identified the eukaryotic parasites by traditional and molecular methodologies coupled with microbial profiling using 16S rDNA sequencing. This mixed methodology approach has allowed us to establish an interesting relationship between Giardia intestinalis and helminth infection, having both effects upon the bacterial gut microbiota enterotypes, causing a switch from a type I to a type II enterotype upon infection. 
1

21 * Corresponding author at: Centro Nacional de Secuenciación Genómica-CNSG,

22 Sede de Investigación Universitaria-SIU, Universidad de Antioquia, Torre 1, S2-13,

23 Carrera 53\#61-30, Medellín, Colombia. Fax: +57 42196402.

24 E-mail address: jfernando.alzate@udea.edu.co (J.F. Alzate). 


\section{ABSTRACT}

27 The study of the burden that parasites can exert upon the bacterial gut microbiota was restricted by the available technologies and their costs. Currently, next-generation sequencing coupled with traditional methodologies allows the study of eukaryotic parasites (protozoa and helminths) and their effects on the human bacterial gut microbiota diversity. This diversity can be altered by a variety of factors such as age, diet, genetics and parasitic infections among others. The disturbances of the gut microbiota have been associated with a variety of illnesses. Infant population in developing countries, are especially susceptible to parasitic infections because of the lack of proper sanitation and undernutrition, allowing both, the thriving of intestinal parasites and profound alteration of the gut microbiota. In this work, we have sampled the stool of 23 children from 4 different children's care-centers in Medellin, Colombia, and we have identified the eukaryotic parasites by traditional and molecular methodologies coupled with microbial profiling using 16S rDNA sequencing. This mixed methodology approach has allowed us to establish an interesting relationship between Giardia intestinalis and helminth infection,

41 having both effects upon the bacterial gut microbiota enterotypes, causing a switch from 42 a type I to a type II enterotype upon infection. 


\section{INTRODUCTION}

The community of hundreds of bacteria species (trillions of individual bacteria) inhabiting the human gastrointestinal tract, plays a paramount role in human health. These microorganisms referred collectively as the gut microbiota (GM) have evolved in association with themselves and with us for millions of years. Human hosts depend upon GM for (i) the acquisition of key nutrients from food, (ii) the shaping of the immune system and (iii) protection from opportunistic pathogens (Greenblum, Turnbaugh \& Borenstein, 2012; Huttenhower et al., 2012; Petrof et al., 2013).

It is estimated that there are -at least- 400 different species of bacteria in the human gastrointestinal tract (Eckburg et al., 2005; Huttenhower et al., 2012). Despite this high number of distinct bacterial taxa, they belong to a relatively low number of phyla (Ley, Peterson \& Gordon, 2006; Ley et al., 2008). To date, more than 50 bacterial phyla have been identified, among them, Bacteroidetes, Firmicutes, Actinobacteria, and Proteobacteria are the most abundant in the human gut. The relative abundance of each one of them might vary between individuals and populations (Blaser \& Falkow, 2009; Huttenhower et al., 2012; Bär et al., 2015).

In recent years, high-throughput technologies -like next-generation sequencing- have allowed an in-depth view of the composition of the GM, its genes, functions, metabolites, and proteins (Morgan \& Huttenhower, 2014). These new technologies and the use of animal models, has shown the importance of the GM when it comes to conferring protection against pathogens and how its dysbiosis (see below), such as those caused by the use of antibiotics, leads to disease (Ubeda \& Pamer, 2012; Ubeda, Djukovic \& Isaac, 2017).

In a healthy state, the GM behaves like a microbial system in which the commensal (or mutual) organisms and the gut mucosal immune system co-exist, evoking the second minimal to non-inflammatory response upon the first. Several factors as age, genetics, xenobiotics, infections and even diet, has a profound impact in the gut microbiota 
76 ecosystem (Lynch \& Pedersen, 2016; Syal, Kashani \& Shih, 2018). It has been suggested

77 that the human bacterial gut microbiota (BGM) composition can be divided into three 78 categories or enterotypes (Arumugam et al., 2011). These enterotypes are usually 79 referred to by the most abundant organism present in a given individual: Bacteroides spp.

80 (Enteroype I), Prevotella spp. (Enterotype II) and members of the order Clostridiales 81 (Enterotype III) (Arumugam et al., 2011; Wu et al., 2011). The fact that inflammatory bowel 82 disease (IBD) do not develop in germ free experimental animals (Sellon et al., 1998), 83 diverted the interest of finding a particular pathogen causing IBD and instead, it shifted 84 over the concept of "dysbiosis" or the imbalance between the beneficial and harmful 85 bacteria in the GM as the main IBD cause (Darfeuille-Michaud et al., 1998; Autschbach 86 et al., 2005; Selby et al., 2007; Syal, Kashani \& Shih, 2018). Various metagenomic analysis has shown in fact, a reduction in the diversity of the BGM in patients with IBD 88 (Manichanh et al., 2006). Besides IBD, extra-intestinal autoimmune disorders like multiple sclerosis and rheumatoid arthritis have also been linked with intestinal dysbiosis, suggesting that BGM may play a role in the development and progression of inflammatory diseases (Belkaid \& Hand, 2014). Other conditions that can be associated with the alterations of GM are obesity, type 2 diabetes, and autism (Marzano et al., 2017).

The human GM is a complex ecosystem encompassing besides bacteria; viruses (mostly bacteriophages), fungi, helminths and protozoa which interact and compete with each other (Filyk \& Osborne, 2016). In order to understand the crosstalk between the different members of the microbiota such as bacteria and eukaryotes, and its effects on the host health/disease processes, it is increasingly important to adopt approaches that allow the overall study of the communities present in human intestines (Chabé, Lokmer \& Ségurel, 2017).

103

104 The effects that parasitic protozoa (Blastocystis spp., Giardia intestinalis, Entamoeba 105 spp., Cryptosporidium spp., etc.) and metazoa (roundworms, whipworms, pinworms, threadworms, hookworms and tapeworms) have on human BGM, has been left-out in 
107 most of the studies because of the particular characteristics of industrialized countries, in 108 which development -it is thought- has depleted the number of parasite-infected 109 individuals and the diversity of the gut microbiota mostly by diet, improved sanitation, the 110 use of food sterilization and antibiotics (Martínez et al., 2015; Chabé, Lokmer \& Ségurel, 111 2017). It is known that the load of these parasites in the population of industrialized 112 countries affects the diversity of the BGM when compared with the few studies carried in 113 non-industrialized counterparts (Chabé, Lokmer \& Ségurel, 2017). Whether the impact of 114 these changes -increased BGM diversity in non-industrialized countries versus lower 115 diversity in industrialized ones- are beneficial for the overall health status of an individual 116 or not, is still to be determined (Blaser \& Falkow, 2009; Segata, 2015; Chabé, Lokmer \& 117 Ségurel, 2017). It is also noteworthy that these studies take into account either the protozoa or the metazoa, but not both at the same time.

When it comes to helminths, for example, it is estimated that more than 1 billion people worldwide are infected by soil-transmitted helminths such as Ascaris lumbricoides and Trichuris trichiura among others. In humans, a study in Sri Lanka in 2017 showed that there is indeed an association with GM diversity in people infected with helminths (Jenkins et al., 2017). It is well known that helminthic parasites release various excretory-secretory products such as immunomodulatory proteins, glycoproteins, and miRNAs that modulate the activity of different cell types including regulatory immune cells. The effects that helminths have on the immune system are so drastic that they have been used for therapeutic purposes (Sipahi \& Baptista, 2017). In developing countries, the children population is especially susceptible to parasite infections due to socioeconomic conditions -like poor sanitation- that allow the transmission of gastrointestinal parasites.

131 Besides, it is known that malnutrition has a synergistic relationship with gastrointestinal

132 infections related to the loss of integrity of the gastrointestinal mucosa (Peterson \& Artis, 133 2014). Interestingly enough, malnutrition is a risk factor and a consequence of intestinal

134 protozoal infection (Ibrahim et al., 2017).

136 Just like helminths, protozoa have been blatantly neglected. Along with rotavirus and 137 bacteria, protozoa parasites are one of the leading causes of diarrhea. In 2010, 
138 approximately 357 million cases of diarrhea were caused either by Entamoeba 139 histolytica., Cryptosporidium spp., or Giardia intestinalis (Naghavi et al., 2015; Gilchrist et 140 al., 2016; Burgess et al., 2017). In the case of Cryptosporidium spp., it has been 141 established as the second aetiological agent of diarrhea in children under 11 months in 142 sub-Saharan Africa and south Asia, and the third for children between 12 and 23 months 143 (Kotloff et al., 2012). Additionally, in the MAL-ED study carried out in South America, 144 Africa, and Asia, researchers have a found Cryptosporidium spp. as the fifth most 145 frequent pathogen in stool samples of children in the ranges of 0-11 and 12-24 months 146 (Platts-Mills et al., 2015). It has been revealed that at least 15 different protozoa genera 147 from diverse groups, either parasitize or commensalize the human gut (Hamad, Raoult \& 148 Bittar, 2016).

150 It has been hypothesized that in humans the infection by G. intestinalis triggers long151 lasting alterations of the commensal microorganisms, promoting bacterial invasiveness 152 in the gut mucosa during its post-clearance phase. This was revealed by a study carried 153 out in mice that showed that damage in the epithelial barrier, cause a host unresolved 154 immune reaction towards its microbiota (Chen et al., 2013). A study that took into account 155 Blastocystis spp., Entamoeba spp., and G. intestinalis in human population in Côte 156 d'Ivoire in 2016, showed a grouping separation between the individuals infected with 157 Giardia and the other parasites, indicating that the microbial communities could be 158 reshaped solely by the presence of Giardia parasites (lebba et al., 2016). These studies 159 suggest that like helminths, protozoa parasites affect the composition of the human 160 bacterial gut microbiota.

162 In Colombia, the latest survey of parasitic diseases in school-aged children revealed that $16330 \%$ of the subjects have soil-transmitted helminths, being the most abundant $T$. trichiura $164(18 \%)$ and $A$. lumbricoides (11\%). Regarding protozoa, Blastocystis spp. (which is no 165 longer classified as protozoa) is the most abundant (52\%) followed by Entamoeba spp. 166 (17\%), G. intestinalis (15\%) and Cryptosporidium spp. (0.5\%). Results of our own survey 167 in Medellín (Colombia) (about to be published), estimates a higher prevalence of $G$. 168 intestinalis (26\%) and Cryptosporidium spp. (1.4\%) compared with the most recent 
169 national survey (Ministerio de Salud y Protección Social \& Universidad de Antioquia, 170 2014).

171

172 This work is a study of the gut microbiota disturbances, considering protozoa and 173 helminths of 23 children with parasitic infections from Medellín, Colombia. Both, the 174 protozoa and metazoa parasites, were identified by microscopy from the stool samples 175 and in the case of Cryptosporidium spp., the species were identified using molecular 176 techniques. The microbiota from the stool was examined by high-throughput sequencing 177 of the V4 variable region of the bacterial 16S rDNA gene followed by bioinformatics and 178 statistical analysis of the sequenced data. To our knowledge, this is one of the few studies 179 that encompasses bacteria, protozoa, and metazoa of the human gut microbiota. 
180 MATERIALS AND METHODS

181

182 Study area and sample population

183 A cross sectional study with non-probabilistic sampling was carried out during 2015 in 184 seven different daycare centers in Medellín - Colombia. All day-care centers are 185 government funded and the children in the study receive a well-balanced diet. Two 186 hundred and ninety feces samples were collected. After parasitical analysis with 187 conventional microscopic techniques, 23 fecal samples were selected for the microbiota 188 analysis. The selection criteria included that only one parasite was detected, in order to 189 reduce noise introduced by cross-infections. In the case of helminth infection, it was not 190 possible to have samples with one single helminth. Therefore, we decided to circumvent 191 this situation by selecting a group of children infected with Ascaris lumbricoides but they 192 were also infected with either Trichuris trichiura or Enterobius vermicularis and most of 193 them were also positive to non-parasitic protozoa or Giardia. This selection criteria 194 reduced the number of groups and samples as follows: i) Group Crypto (Cryptosporidium 195 detected, no other parasites observed): 5 individuals; ii) Group Giardia (Giardia detected, 196 no other parasites observed): 6 children; iii) Group Helm-pro (Ascaris detected, and were 197 coinfected with either Trichuris trichiura or Enterobius vermicularis. Most of them with 198 accompanying non-parasitic protozoa or Giardia) 6 children; and iv) Group control (No 199 parasites detected): 6 children (Table 1).

\section{Fecal sample collection, parasitical analysis, DNA extraction}

Stool samples were collected in screw-capped containers (no preservative) and immediately transported to the lab where they were analyzed by two methods, direct microscopic examination and modified Ritchie concentration. The modified Ziehl-Neelsen stain was used for detection of intestinal apicomplexan. The samples were frozen at $20^{\circ} \mathrm{C}$ prior DNA extraction for microbiota analysis and Cryptosporidium spp. assignation. the small-subunit (SSU) rRNA gene, according to the protocol described by Xiao et al (Xiao et al., 1999, 2001). The DNA was purified using a stool DNA isolation kit (Norgen Biotek, Thorold, ON, Canada), according to manufacturer's instructions. 


\section{Amplification and sequencing of 16S rDNA variable 4 region}

213 DNA concentration was assessed using fluorescent dye picogreen. Additionally, the

214 quality of bacterial DNA was tested using an initial amplification of the full-length 16S

215 rDNA gene, using 27F and 1492R primers. The samples were sequenced by Illumina

216 MiSeq platform with paired reads of $250 \mathrm{bp}$. where the V4 hypervariable region of the 16S

217 rDNA gene was amplified using the Hyb515F_rRNA (GTTTGATCMTGGCTCAG) and

218 Hyb806_rRNA (TGCCTCCCGTAGGAGT) primers with the respective Illumina adapters

219 and barcodes.

220 Raw sequencing data was deposited at the NCBI SRA database under the project 221 PRJNA487588.

222

223 Sequenced 165 rDNA processing and analysis

224 MOTHUR software package (v 1.39.5) was used for sequenced data processing 225 according to the MiSeq Standard Operating Procedure (SOP). Low quality and 226 nonspecific reads were detected and excluded with the screen.seqs command. The 227 chimeric sequences were identified and discarded using the VSEARCH program included 228 in the package. The Operations Taxonomic Units (OTUs) were defined at 97\% followed 229 by taxonomy assignment using the RDP reference database sequences as a guide.

230 Singletons and OTUs identified as both, chloroplasts and mitochondria, were discarded.

\section{Alpha \& Beta diversity metrics}

233 Sample coverage (good's coverage), richness (CHAO index), diversity (Shannon and 234 Inverse Simpson index) and the number of observed OTUs, were obtained with MOTHUR 235 (Table 2). To visualize differences in microbial community structures based on species 236 abundances, $\theta_{Y C}$ dissimilarity matrices were generated from OTU tables and 237 subsequently subjected to PCoA analysis and visualized in R. $\theta_{Y C}$ dissimilarities were 238 calculated using MOTHUR and used to compare samples, upon which analysis of 239 molecular variance (AMOVA) were performed using the MOTHUR integrated version 240 (Schloss et al., 2009). The OTU tables from MOTHUR were exported as a BIOM file and 
241 used in the Metagenomics Core Microbiome Exploration Tool (MetaCoMET) to generate 242 the diversity plots (Wang et al., 2016). The images were further modified using Inkscape. 243

\section{Ethics committee approval}

245 The ethical clearance of this study was followed by the ethics of Helsinki declaration and 246 resolution No. 008430 of 1993 from the Ministry of Health from Colombia. The study was 247 approved by the Ethics Committee from Sede de Investigación Universitaria, Universidad 248 de Antioquia, under the official document $\mathrm{N}^{\circ} 14-06-564$.

249

250 
251

252

253

254

255

256

257

258

259

260

261

262

263

264

265

266

267

268

269

270

271

272

273

274

275

276

277

278

279

280

281

282

\section{RESULTS}

From the 290 collected fecal samples, nearly $39 \%$ were negative for intestinal parasites and 23 were selected for this study according to the parasites detected. The samples were grouped as follow: (i) Controls: the samples in which it was not possible to detect any known parasite; (ii) Crypto: the samples of children that were infected by Cryptosporidium spp.. Some of them also had non-parasitic protozoa; (iii) Giardia: the samples of children infected with Giardia intestinalis and (iv) Helm-Pro: mixed samples of children infected by Ascaris lumbricoides, some of them with either Trichuris trichiura or Enterobius vermicularis and most of them with accompanying non-parasitic protozoa or Giardia sp. All the samples with helminthic parasites were accompanied by either protozoa or blastocystis, reason why it is not possible to have a group of individuals infected solely by helminths. The groupings and other features of each sample are indicated in Table 1.

After the bioinformatic processing of the reads the with the MOTHUR package, the number of clean sequences (excluding low-quality, too short, non-bacterial and chimeric reads) in the studied samples ranged between 3319 and 57133. The Good's coverage estimator values of the samples ranged from 0.982 to 0.997 .

The Shannon index -which shows the diversity of species in each community- present significative difference between the assessed groups (Figure 1, panel A). Though this result seems counter-intuitive because the Shannon indexes changes observed in parasite infected individuals, this low Shannon among all the groups might be associated with the age of the population $(<5 \mathrm{y} / 0)$. Interestingly enough, the number of observed species in the Helm-pro group is higher than those found in the other groups, suggesting that the infection with helminths (more specifically nematodes) have an effect on the total number of bacterial species observed in the children gut (Figure 1, panel B).

When the BGM is compared between groups at genera level (Figure 2), there is a evident change between the Control and the Helm-Pro and Giardia groups with an enrichment of Prevotella spp. at expense of Bacteroides spp. Additionally, as the Figure $\mathbf{3}$ shows, a 
283 comparison of the microbiota of each of the sample within the different groups in all the 284 ranks, there is a clear difference in the population composition with an enrichment of the 285 Prevotellaceae family in Giardia and Helm-Pro groups at the expense of the 286 Bacteroidaceae family; more abundant in the Control and some Crypto samples.

288 Likewise, Prevotella genus is the most enriched genera in the Helm-Pro and Giardia 289 groups and the Bacteroides in the Controls and Crypto groups. Principal coordinates analysis (PCoA) showed an explicit grouping in the structure of the bacterial communities

291 of the Giardia and Helm-Pro groups and the dissimilarities of these with those of the 292 Control and Crypto (Figure 4, panel A).

293 These results combined, show a strong correlation between the change in the enterotype 294 of the individuals when these are infected with the protozoan parasite Giardia sp. and 295 helminths. These results are corroborated by the AMOVA analysis that shows a significant variance of the control with either giardia $(p$-value $=0.006)$ or helm-pro $(p$ value $=0.014)$ groups $($ Table 3$)$. No other group comparison showed significant variance 298 between them.

299 To help us better understand the differences underlying between the groups we used a 300 Venn diagram (Figure 4, panel B) that group the different OTUs found in all the groups 301 and how they relate, especially those that intersect between Giardia and Helm-Pro. The 3022 most abundant OTUs in the shared microbiota of Helm-Pro and Giardia are from 303 Prevotella species (51\%) and unclassified Porphyromonadaceae species from the 304 bacteroidetes Phylum (Figure 5, panel A), likewise, in the unique Helm-Pro OTUs, the 305 most abundant genera are also from the same phyla, Alloprevotella $(40 \%)$ and Prevotella 306 (16\%) (Figure 5, panel B). In contrast, in the unique Giardia OTUs, the most abundant 307 bacteria are Ruminococcus (17\%) from the Firmicutes Phylum and in second place 308 Prevotella species (12\%) (Figure 5, panel C). 


\section{DISCUSSION}

314

315 Different from the concept of pathogenicity that can be associated to a species or

316 subspecies of bacteria, dysbiosis can be challenging to define as it could be considered

317 a perturbation of the balanced ecology of an established system, in this case the gut

318 microbiota.

319 To study the effect that parasites cause upon the bacterial community residing in the

320 human gut, we used primers that target the $16 \mathrm{~S}$ gene V4 hypervariable region observing

321 up to 360 bacterial species (Figure 1, panel B and Table 2).

322 As expected, we found the organisms that define the enterotypes to be the most common

323 in the children studied in Medellín (Figure 2 and Figure 3). From our results we can

324 conclude that the children from the control group are mainly associated with a type I

325 enterotype (defined by Bacteroides spp.) which is switched to a type II enterotype

326 (determined by Prevotella spp.) upon infection with helminths and Giardia intestinalis

327 parasites. This is a striking result for two reasons: (i) Changing enterotypes in humans is

328 not easy to achieve (Wu et al., 2011; Yin et al., 2017), for instance, a study of 10 subjects

329 who were subjected to a dietary change from high-fat/low-fiber to low-fat/high-fiber, did

330 indeed modulated the BGM but they did not change the enterotype (Wu et al., 2011;

331 Roager et al., 2014); and (ii), since the enterotypes are associated with long-term dietary

332 habits, and these are somewhat different between industrialized countries and developing

333 ones (De Filippo et al., 2010), it would be reasonable to assume that populations from the

334 same region (in this case the same city) with similar diet, would have the same

335 enterotypes (Yatsunenko et al., 2012). All the sampled children were from close locations

336 in an urban settlement within a $16 \mathrm{~km}^{2}$ area. If the shift of enterotypes elicited by the

337 parasite's infection is permanent or reversible, as shown in mice upon the clearance of

338 the parasites (Houlden et al., 2015), is yet to be determined. We are well aware of the

339 studies that claim that the enterotypes construction might be not that accurate, and that

340 instead the BGM is a gradient of species (Caporaso et al., 2011; Knights et al., 2014),

341 nevertheless, because of the simplicity of the enterotypes model compared with the

342 gradient one and the adherence of our data to the former, we have decided to discuss

343 our results using the enterotypes model. 
344 The type I enterotype has been associated to individuals with a westernized diet rich in

345 animal protein and it is the most common enterotype in industrialized countries, whereas

346 type II enterotype is associated with developing nations and a diet rich in carbohydrates

347 (De Filippo et al., 2010; Ou et al., 2013). In fact, Prevotella spp. is abundant in the BGM

348 of cattle and goats (Flint et al., 2008). It is noteworthy that the human populations with

349 high prevalence of helminths studied so far are very distinct in lifestyle and diet from

350 industrialized areas (De Filippo et al., 2010; Reynolds, Finlay \& Maizels, 2015).

351 The type I and II enterotypes behave differently in fiber degradation and metabolites

352 production. For instance, type II enterotype is more prone to produce propionate and

353 butyrate as by-products of fiber degradation, being the latest a known inflammatory

354 modulator (Chen et al., 2017). This is particularly interesting considering that it has been

355 suggested that a potential mechanism by which helminths alter the BGM composition is

356 affecting the host immune system disrupting the interaction between the bacteria and the

357 host (Resende Co et al., 2007; Degarege et al., 2012; Brosschot \& Reynolds, 2018). For

358 example, it is known that in rats Hymenolepis diminuta establishes long-term colonization

359 that has an immunomodulatory effect on the host without causing bacterial dysbiosis

360 (Parfrey et al., 2017). Another impact of helminthic infection is either a decrease or an

361 increase of species observed in mice and humans respectively (Lee et al., 2014; Houlden

362 et al., 2015).

363 Nevertheless, in our study there is not a clear distinction between the controls and the

364 infected groups (Figure 1, panel A), this can be attributable to the young age of the

365 individuals surveyed as it has been shown that the BGM diversity in children is low and

366 increases with age (Odamaki et al., 2016). In humans, a study in Sri Lanka in 2017

367 showed that there is indeed an association with GM diversity in people infected with

368 helminths (Jenkins et al., 2017). Previous studies had shown a discrepancy between the

369 effect of Trichuris trichiura on the GM; on 2013 Lee et al. demonstrated an increase in

370 diversity and abundance of some Paraprevotellacae bacteria in individuals infected by $T$.

371 trichiura (Lee et al., 2014). On the other hand, Cooper at al. showed that in Ecuadorian

372 children $T$. trichiura infection does not have an effect on the gut microbiota and instead,

373 it is A. lumbricoides parasite colonization the one that drives the GM changes (Cooper et

374 al., 2013). This is particularly relevant to this study because the helm-pro group was 
375 designed considering the presence of $A$. lumbricoides as the primary determinant in the 376 group, even when some of the individuals also had a T. trichiura co-infection.

377 Even though there seems to be a consensus about the beneficial immunomodulatory role 378 of helminths during infection, the role that protozoa might play or not -immunologically 379 speaking - in the human host is not yet clear, and most of the studies made so far are in 380 murine models. For instance, in mice the colonization by Tritrichomonas musculis leads 381 to inflammasome activation, promoting the release of the pro-inflammatory cytokine IL38218 and preventing infection by bacteria (Chudnovskiy et al., 2016). Also, in mice, Giardia's 383 cysteine secretory/excretory proteases could induce abnormalities in the biofilm 384 architecture of the host microbiota allowing bacterial invasion. These dysbiotic microbial 385 communities stimulate the activation of TRL signaling pathway 4 and the overproduction of proinflammatory cytokine IL-1 $\beta$ (Beatty et al., 2017). The impact of Giardia infection in the BGM in mice has also been studied by Barash et al.. Their findings indicate a systemic dysbiosis of aerobic and anaerobic commensal bacteria, characterized by higher levels of aerobic microorganisms and lower levels of anaerobic ones such as those from the Firmicutes phylum (Lactobacillaceae, Eryipelotichaeae, Ruminococcus, and Clostridia).

391 They proposed that the dysbiosis observed could be mediated by the anaerobic Giardia

392 metabolism and the stimulation of gut inflammation (Gevers et al., 2014; Barash et al., 393 2017).

394 We have found that just as observed in the Helm-pro group, the Giardia group also shifts 395 the enterotype from I to II (Figure 2 and Figure 3 ) and, as shown by the PCoA analysis 396 (Figure 4, panel A), half of the samples of this group clusters with the Helm-Pro one. So 397 even if the mechanisms by which they exert the changes in the gut microbiota are 398 different, the effect of the $A$. lumbricoides and $G$. intestinalis in the human BGM is 399 somewhat similar. Opposite to the results observed by Barash in mice, we found that in 400 the Giardia group -besides the switch to the type II enterotype- there is a higher level of 401 Roseburia spp. (Figure 2), an anaerobic bacteria known as a "maker of health" for the 402 high butyrate production, that as mentioned before, may be necessary for the control of 403 inflammatory processes in the gut (Tamanai-Shacoori et al., 2017). Another discrepancy 404 that we found regarding the anaerobes depletion expected in Giardia infection, is that in 405 the unique Giardia OTUs, since the most abundant (17\%) is Ruminococcus spp., a 
406 Firmicutes phylum bacteria (Figure 5). If the findings of higher levels of the anaerobic

407 Roseburia in the Giardia group and of Ruminococcus in the unique Giardia OTUs, are 408 relevant or a mere curiosity of this dataset, is yet to be determined.

409 The last group of this study (Crypto), is formed by individuals infected with 410 Cryptosporidium spp.. Just as with the Giardia group, Crypto also displayed a rise in the

411 Firmicutes phylum, especially of Bifidobacterium spp. Which is believed to exert health 412 benefits on their hosts (O'Callaghan \& van Sinderen, 2016). It has been suggested that

413 the use of Bifidobacterium spp. as probiotics reduces the incidence of diarrhea in infants 414 possibly by the competition of adherence sites on epithelial cells with other 415 microorganisms (Corrêa et al., 2005; Gueimonde et al., 2007; O'Callaghan \& van 416 Sinderen, 2016).

417 Nevertheless, the AMOVA analysis did not support significant differences between the 418 Crypto and Control groups, maybe because of the microbial populations disparity 419 displayed by the members of the former. The parasite Cryptosporidium spp. is rather 420 different from helminths and $G$. intestinalis because it multiplies inside of intestinal 421 enterocytes, so the effects that it might have upon GM could be indirect and related to the 422 loss of integrity of the epithelium (Moore et al., 1995). Still, the effects that the short-lived 423 extracellular stages of the parasite (Sporozoites, merozoites, microgametes and oocysts) 424 can have upon the BGM cannot be wholly ruled out. In developing countries, children 425 cryptosporidiosis also contributes to malnutrition, immunosuppression and stunting 426 (Guerrant, 1997). Although studies of the effect of Cryptosporidium spp. on human BGM 427 are rather lacking, encouraging rodent models help us to devise that there is indeed an 428 effect of these parasites on the BGM (Ras et al., 2015). The different Cryptosporidium 429 species that we found in our study group differentially in the PCoA analysis and display a 430 different array of species abundance (Figure 4, panel A). For instance, there is a discrete 431 grouping of samples of the Helm-Pro and Giardia groups with one outsider sample 432 belonging to the Crypto group in it (Figure 4, panel A green circles). When it comes to 433 the abundance profile shown in the bacterial microbiota, there is also a difference of the 434 sample above with its Crypto group and a closer resemblance with the abundance 435 distribution found in the Helm-Pro and Giardia groups (Figure 4, panel A). This particular 436 sample (ED15) belongs to one child infected with a zoonotic avian species of 
437 Cryptosporidium (C. meleagridis), the other children in the same group were infected with 438 C. hominis (Table 1).

439

440 Overall, we found that the children infected with either the Giardia intestinalis protozoa or 441 a mix of helminths such as Ascaris lumbricoides along with Trichuris trichiura, and other parasitic protozoa causes a switch of enterotype from I to II in children. To our knowledge, this is the first study of the effects of human parasites in human gut microbiota in an urban setting. This study in children is particularly relevant because it has been hypothesized that the disturbance in the gut microbiota by helminths, can have an effect in the cognition and behavior of this susceptible

\section{Conclusions}

450

This study is just a glimpse in the incidence of parasite infection in the human bacterial gut microbiota in developing countries, and to draw sturdier hypothesis about the human parasites and the BGM interaction, it is necessary a more thorough study with a more 454 comprehensive dataset.

455 Our results support the observation that the presence of Intestinal parasites in children, mainly Giardia and Helminths as Ascaris, exerts an effect upon the gut microbiota affecting the equilibria of bacterial communities. Nonetheless, not all parasites had the same influence on the bacterial populations, for instance, Cryptosporidium spp. showed no significant alterations of the bacterial microbiota in terms of diversity and structure. Future works should aim to elucidate the causal relation of the parasite arrival into the intestine and bacterial community structure changes. 


\section{References}

466 Arumugam M., Raes J., Pelletier E., Le Paslier D., Yamada T., Mende DR., Fernandes

467

468

469

470

471

472

473

474

475

476

477

478

479

480

481

482

483

484

485

486

487

488

489

490

491

492

493

494 GR., Tap J., Bruls T., Batto JM., Bertalan M., Borruel N., Casellas F., Fernandez L., Gautier L., Hansen T., Hattori M., Hayashi T., Kleerebezem M., Kurokawa K., Leclerc M., Levenez F., Manichanh C., Nielsen HB., Nielsen T., Pons N., Poulain J., Qin J., Sicheritz-Ponten T., Tims S., Torrents D., Ugarte E., Zoetendal EG., Wang J., Guarner F., Pedersen O., De Vos WM., Brunak S., Doré J., Weissenbach J., Ehrlich SD., Bork P. 2011. Enterotypes of the human gut microbiome. Nature 473:174-180. DOI: 10.1038/nature09944.

Autschbach F., Eisold S., Hinz U., Zinser S., Linnebacher M., Giese T., Löffler T., Büchler MW., Schmidt J. 2005. High prevalence of Mycobacterium avium subspecies paratuberculosis IS900 DNA in gut tissues from individuals with Crohn's disease. Gut 54:944-949. DOI: 10.1136/gut.2004.045526.

Bär AK., Phukan N., Pinheiro J., Simoes-Barbosa A. 2015. The Interplay of Host Microbiota and Parasitic Protozoans at Mucosal Interfaces: Implications for the Outcomes of Infections and Diseases. PLoS Neglected Tropical Diseases 9:1-12. DOI: 10.1371/journal.pntd.0004176.

Barash NR., Maloney JG., Singer SM., Dawson SC. 2017. Giardia Alters Commensal Microbial Diversity throughout the Murine Gut. Infection and Immunity 85:1-18. DOI: 10.1128/IAI.00948-16.

Beatty JK., Akierman S V., Motta JP., Muise S., Workentine ML., Harrison JJ., Bhargava A., Beck PL., Rioux KP., McKnight GW., Wallace JL., Buret AG. 2017. Giardia duodenalis induces pathogenic dysbiosis of human intestinal microbiota biofilms. International Journal for Parasitology 47:311-326. DOI:

10.1016/j.ijpara.2016.11.010.

Belkaid Y., Hand TW. 2014. Role of the microbiota in immunity and inflammation. Cell 157:121-141. DOI: 10.1016/j.cell.2014.03.011.

Blaser MJ., Falkow S. 2009. What are the consequences of the disappearing human microbiota? Nature Reviews Microbiology 7:887-894. DOI: 10.1038/nrmicro2245.

Brosschot TP., Reynolds LA. 2018. The impact of a helminth-modified microbiome on 
495

496

497

498

499

500

501

502

503

504

505

506

507

508

509

510

511

512

513

514

515

516

517

518

519

520

521

522

523

524

host immunity. Mucosal Immunology:1-8. DOI: 10.1038/s41385-018-0008-5.

Burgess SL., Gilchrist CA., Lynn TC., Petri Jr. WA. 2017. Parasitic Protozoa and Interactions with the Host Intestinal Microbiota. Infection and Immunity 85:1-12. DOI: 10.1128/IAI.00101-17.

Caporaso JG., Lauber CL., Costello EK., Berg-Lyons D., Gonzalez A., Stombaugh J., Knights D., Gajer P., Ravel J., Fierer N., Gordon JI., Knight R. 2011. Moving pictures of the human microbiome. Genome Biology 12. DOI: 10.1186/gb-2011-125-r50.

Chabé M., Lokmer A., Ségurel L. 2017. Gut Protozoa: Friends or Foes of the Human Gut Microbiota? Trends in Parasitology 33:925-934. DOI: 10.1016/j.pt.2017.08.005.

Chen TL., Chen S., Wu HW., Lee TC., Lu YZ., Wu LL., Ni YH., Sun CH., Yu WH., Buret AG., Yu LCH. 2013. Persistent gut barrier damage and commensal bacterial influx following eradication of Giardia infection in mice. Gut Pathogens 5. DOI: 10.1186/1757-4749-5-26.

Chen T., Long W., Zhang C., Liu S., Zhao L., Hamaker BR. 2017. Fiber-utilizing capacity varies in Prevotella- versus Bacteroides-dominated gut microbiota. Scientific Reports 7:1-7. DOI: 10.1038/s41598-017-02995-4.

Chudnovskiy A., Mortha A., Kana V., Kennard A., Ramirez JD., Rahman A., Remark R., Mogno I., Ng R., Gnjatic S., Amir E ad D., Solovyov A., Greenbaum B., Clemente J., Faith J., Belkaid Y., Grigg ME., Merad M. 2016. Host-Protozoan Interactions Protect from Mucosal Infections through Activation of the Inflammasome. Cell 167:444-456.e14. DOI: 10.1016/j.cell.2016.08.076.

Cooper P., Walker AW., Reyes J., Chico M., Salter SJ., Vaca M., Parkhill J. 2013. Patent Human Infections with the Whipworm, Trichuris trichiura, Are Not Associated with Alterations in the Faecal Microbiota. PLOS ONE 8. DOI: 10.1371/journal.pone.0076573.

Corrêa NBO., Péret Filho LA., Penna FJ., Lima FMLS., Nicoli JR. 2005. A randomized formula controlled trial of Bifidobacterium lactis and Streptococcus thermophilus for prevention of antibiotic-associated diarrhea in infants. Journal of Clinical 
Gastroenterology. DOI: 10.1097/01.mcg.0000159217.47419.5b.

526 Darfeuille-Michaud A., Neut C., Barnich N., Lederman E., Di Martino P., Desreumaux

P., Gambiez L., Joly B., Cortot A., Colombel J-F. 1998. Presence of adherent

Escherichia coli strains in ileal mucosa of patients with Crohn's disease.

Gastroenterology 115:1405-1413. DOI: 10.1016/S0016-5085(98)70019-8.

530

531

532

533

534

535

536

537

538

539

540

541

542

543

544

545

546

547

548

549

550

551

552

553

554

Degarege A., Legesse M., Medhin G., Animut A., Erko B. 2012. Malaria and related outcomes in patients with intestinal helminths: A cross-sectional study. BMC Infectious Diseases 12. DOI: 10.1186/1471-2334-12-291.

Eckburg PB., Bik EM., Bernstein CN., Purdom E., Dethlefsen L., Sargent M., Gill SR., Nelson KE., Relman DA. 2005. Diversity of the human intestinal microbial flora. Science (New York, N.Y.) 308:1635-8. DOI: 10.1126/science.1110591.

De Filippo C., Cavalieri D., Di Paola M., Ramazzotti M., Poullet JB., Massart S., Collini S., Pieraccini G., Lionetti P. 2010. Impact of diet in shaping gut microbiota revealed by a comparative study in children from Europe and rural Africa. Proceedings of the National Academy of Sciences 107:14691-14696. DOI: 10.1073/pnas.1005963107.

Filyk HA., Osborne LC. 2016. The Multibiome: The Intestinal Ecosystem's Influence on Immune Homeostasis, Health, and Disease. EBioMedicine 13:46-54. DOI: 10.1016/j.ebiom.2016.10.007.

Flint HJ., Bayer EA., Rincon MT., Lamed R., White BA. 2008. Polysaccharide utilization by gut bacteria: Potential for new insights from genomic analysis. Nature Reviews Microbiology 6:121-131. DOI: 10.1038/nrmicro1817.

Gevers D., Kugathasan S., Denson LA., Vázquez-Baeza Y., Van Treuren W., Ren B., Schwager E., Knights D., Song SJ., Yassour M., Morgan XC., Kostic AD., Luo C., González A., McDonald D., Haberman Y., Walters T., Baker S., Rosh J., Stephens M., Heyman M., Markowitz J., Baldassano R., Griffiths A., Sylvester F., Mack D., Kim S., Crandall W., Hyams J., Huttenhower C., Knight R., Xavier RJ. 2014. The treatment-naive microbiome in new-onset Crohn's disease. Cell Host and Microbe. DOI: 10.1016/j.chom.2014.02.005.

Gilchrist CA., Petri SE., Schneider BN., Reichman DJ., Jiang N., Begum S., Watanabe K., Jansen CS., Elliott KP., Burgess SL., Ma JZ., Alam M., Kabir M., Haque R., 
555

556

557

558

559

560

561

562

563

564

565

566

567

568

569

570

571

572

573

574

575

576

577

578

579

580

581

582

583

584

Petri WA. 2016. Role of the Gut Microbiota of Children in Diarrhea Due to the Protozoan Parasite Entamoeba histolytica. Journal of Infectious Diseases 213:1579-1585. DOI: 10.1093/infdis/jiv772.

Greenblum S., Turnbaugh PJ., Borenstein E. 2012. Metagenomic systems biology of the human gut microbiome reveals topological shifts associated with obesity and in $\mathrm{fl}$ ammatory bowel disease. Proceedings of the National Academy of Sciences 109:594-599. DOI: 10.1073/pnas.1116053109//DCSupplemental.www.pnas.org/cgi/doi/10.1073/pnas.1116053109.

Gueimonde M., Margolles A., de los Reyes-Gavilán CG., Salminen S. 2007. Competitive exclusion of enteropathogens from human intestinal mucus by Bifidobacterium strains with acquired resistance to bile--a preliminary study. International journal of food microbiology. DOI: 10.1016/j.ijfoodmicro.2006.05.017.

Guernier V., Brennan B., Yakob L., Milinovich G., Clements ACA., Soares Magalhaes RJ. 2017. Gut microbiota disturbance during helminth infection: Can it affect cognition and behaviour of children? BMC Infectious Diseases 17:1-6. DOI: 10.1186/s12879-016-2146-2.

Guerrant RL. 1997. Cryptosporidiosis: An Emerging, Highly Infectious Threat. Emerging Infectious Diseases 3:51-57. DOI: 10.3201/eid0301.970106.

Hamad I., Raoult D., Bittar F. 2016. Repertory of eukaryotes (eukaryome) in the human gastrointestinal tract: Taxonomy and detection methods. Parasite Immunology 38:12-36. DOI: 10.1111/pim.12284.

Houlden A., Hayes KS., Bancroft AJ., Worthington JJ., Wang P., Grencis RK., Roberts IS. 2015. Chronic Trichuris muris infection in C57BL/6 mice causes significant changes in host microbiota and metabolome: Effects reversed by pathogen clearance. PLOS ONE 10. DOI: 10.1371/journal.pone.0125945.

Huttenhower C., Gevers D., Knight R., Abubucker S., Badger JH., Chinwalla AT., Creasy HH., Earl AM., Fitzgerald MG., Fulton RS., Giglio MG., Hallsworth-Pepin K., Lobos EA., Madupu R., Magrini V., Martin JC., Mitreva M., Muzny DM., Sodergren EJ., Versalovic J., Wollam AM., Worley KC., Wortman JR., Young SK., Zeng Q., Aagaard KM., Abolude OO., Allen-Vercoe E., Alm EJ., Alvarado L., Andersen GL., 
Anderson S., Appelbaum E., Arachchi HM., Armitage G., Arze CA., Ayvaz T., Baker CC., Begg L., Belachew T., Bhonagiri V., Bihan M., Blaser MJ., Bloom T., Bonazzi V., Paul Brooks J., Buck GA., Buhay CJ., Busam DA., Campbell JL., Canon SR., Cantarel BL., Chain PSG., Chen IMA., Chen L., Chhibba S., Chu K., Ciulla DM., Clemente JC., Clifton SW., Conlan S., Crabtree J., Cutting MA., Davidovics NJ., Davis CC., Desantis TZ., Deal C., Delehaunty KD., Dewhirst FE., Deych E., Ding Y., Dooling DJ., Dugan SP., Michael Dunne W., Scott Durkin A., Edgar RC., Erlich RL., Farmer CN., Farrell RM., Faust K., Feldgarden M., Felix VM., Fisher S., Fodor AA., Forney LJ., Foster L., Di Francesco V., Friedman J., Friedrich DC., Fronick CC., Fulton LL., Gao H., Garcia N., Giannoukos G., Giblin C., Giovanni MY., Goldberg JM., Goll J., Gonzalez A., Griggs A., Gujja S., Kinder Haake S., Haas BJ., Hamilton HA., Harris EL., Hepburn TA., Herter B., Hoffmann DE., Holder ME., Howarth C., Huang KH., Huse SM., Izard J., Jansson JK., Jiang H., Jordan C., Joshi V., Katancik JA., Keitel WA., Kelley ST., Kells C., King NB., Knights D., Kong HH., Koren O., Koren S., Kota KC., Kovar CL., Kyrpides NC., La Rosa PS., Lee SL., Lemon KP., Lennon N., Lewis CM., Lewis L., Ley RE., Li K., Liolios K., Liu B., Liu Y., Lo CC., Lozupone CA., Dwayne Lunsford R., Madden T., Mahurkar AA., Mannon PJ., Mardis ER., Markowitz VM., Mavromatis K., McCorrison JM., McDonald D., McEwen J., McGuire AL., McInnes P., Mehta T., Mihindukulasuriya KA., Miller JR., Minx PJ., Newsham I., Nusbaum C., Oglaughlin M., Orvis J., Pagani I., Palaniappan K., Patel SM., Pearson M., Peterson J., Podar M., Pohl C., Pollard KS., Pop M., Priest ME., Proctor LM., Qin X., Raes J., Ravel J., Reid JG., Rho M., Rhodes R., Riehle KP., Rivera MC., Rodriguez-Mueller B., Rogers YH., Ross MC., Russ C., Sanka RK., Sankar P., Fah Sathirapongsasuti J., Schloss JA., Schloss PD., Schmidt TM., Scholz M., Schriml L., Schubert AM., Segata N., Segre JA., Shannon WD., Sharp RR., Sharpton TJ., Shenoy N., Sheth NU., Simone GA., Singh I., Smillie CS., Sobel JD., Sommer DD., Spicer P., Sutton GG., Sykes SM., Tabbaa DG., Thiagarajan M., Tomlinson CM., Torralba M., Treangen TJ., Truty RM., Vishnivetskaya TA., Walker J., Wang L., Wang Z., Ward D V., Warren W., Watson MA., Wellington C., Wetterstrand KA., White JR., Wilczek-Boney K., Wu Y., Wylie KM., Wylie T., Yandava C., Ye L., Ye Y., Yooseph S., Youmans BP., Zhang 
616

617

618

619

620

621

622

623

624

625

626

627

628

629

630

631

632

633

634

635

636

637

638

639

640

641

642

643

644

645

L., Zhou Y., Zhu Y., Zoloth L., Zucker JD., Birren BW., Gibbs RA., Highlander SK., Methé BA., Nelson KE., Petrosino JF., Weinstock GM., Wilson RK., White O. 2012. Structure, function and diversity of the healthy human microbiome. Nature 486:207-214. DOI: 10.1038/nature11234.

Ibrahim MK., Zambruni M., Melby CL., Melby PC. 2017. Impact of childhood malnutrition on host defense and infection. Clinical Microbiology Reviews 30:919-971. DOI: http://dx.doi.org/10.1128/CMR.00119-16.

lebba V., Santangelo F., Totino V., Pantanella F., Monsia A., Di Cristanziano V., Di Cave D., Schippa S., Berrilli F., D’Alfonso R. 2016. Gut microbiota related to Giardia duodenalis, Entamoeba spp. and Blastocystis hominis infections in humans from Cï ¿ 1/2te D'ivoire. Journal of Infection in Developing Countries 10:1035-1041. DOI: $10.3855 /$ jidc. 8179 .

Jenkins TP., Rathnayaka Y., Perera PK., Peachey LE., Nolan MJ., Krause L., Rajakaruna RS., Cantacessi C. 2017. Infections by human gastrointestinal helminths are associated with changes in faecal microbiota diversity and composition. PLoS ONE 12:1-18. DOI: 10.1371/journal.pone.0184719.

Knights D., Ward TL., McKinlay CE., Miller H., Gonzalez A., McDonald D., Knight R. 2014. Rethinking enterotypes. Cell Host and Microbe 16:433-437. DOI: 10.1016/j.chom.2014.09.013.

Kotloff KL., Blackwelder WC., Nasrin D., Nataro JP., Farag TH., Van Eijk A., Adegbola RA., Alonso PL., Breiman RF., Golam Faruque AS., Saha D., Sow SO., Sur D., Zaidi AKM., Biswas K., Panchalingam S., Clemens JD., Cohen D., Glass RI., Mintz ED., Sommerfelt H., Levine MM. 2012. The Global Enteric Multicenter Study (GEMS) of diarrheal disease in infants and young children in developing countries: Epidemiologic and clinical methods of the case/control study. Clinical Infectious Diseases 55. DOI: 10.1093/cid/cis753.

Lee SC., Tang MS., Lim YAL., Choy SH., Kurtz ZD., Cox LM., Gundra UM., Cho I., Bonneau R., Blaser MJ., Chua KH., Loke P. 2014. Helminth Colonization Is Associated with Increased Diversity of the Gut Microbiota. PLoS Neglected Tropical Diseases 8. DOI: 10.1371/journal.pntd.0002880. 
646 Ley RE., Hamady M., Lozupone C., Turnbaugh PJ., Ramey RR., Bircher JS., Schlegel

647

648

649

650

651

652

653

654

655

656

657

658

659

660

661

662

663

664

665

666

667

668

669

670

671

672

673

674

675

ML., Tucker TA., Schrenzel MD., Knight R., Gordon JI. 2008. Evolution of mammals and their gut microbes. Science (New York, N.Y.) 320:1647-51. DOI: 10.1126/science.1155725.

Ley RE., Peterson DA., Gordon JI. 2006. Ecological and evolutionary forces shaping microbial diversity in the human intestine. Cell 124:837-848. DOI:

10.1016/j.cell.2006.02.017.

Lynch S V., Pedersen O. 2016. The Human Intestinal Microbiome in Health and Disease. New England Journal of Medicine 375:2369-2379. DOI: 10.1056/NEJMra1600266.

Manichanh C., Rigottier-Gois L., Bonnaud E., Gloux K., Pelletier E., Frangeul L., Nalin R., Jarrin C., Chardon P., Marteau P., Roca J., Dore J. 2006. Reduced diversity of faecal microbiota in Crohn's disease revealed by a metagenomic approach. Gut 55:205-211. DOI: 10.1136/gut.2005.073817.

Martínez I., Stegen JC., Maldonado-Gómez MX., Eren AM., Siba PM., Greenhill AR., Walter J. 2015. The Gut Microbiota of Rural Papua New Guineans: Composition, Diversity Patterns, and Ecological Processes. Cell Reports 11:527-538. DOI: 10.1016/J.CELREP.2015.03.049.

Marzano V., Mancinelli L., Bracaglia G., Del Chierico F., Vernocchi P., Di Girolamo F., Garrone S., Tchidjou Kuekou H., D’Argenio P., Dallapiccola B., Urbani A., Putignani L. 2017. "Omic" investigations of protozoa and worms for a deeper understanding of the human gut "parasitome." PLOS Neglected Tropical Diseases 11:e0005916. DOI: 10.1371/journal.pntd.0005916.

Ministerio de Salud y Protección Social \& Universidad de Antioquia. 2014. ENCUESTA NACIONAL DE PARASITISMO INTESTINAL EN POBLACIÓN ESCOLAR COLOMBIA, 2012 - 2014 (Análisis en profundidad). Medellín: Facultad Nacional Salud Pública, Universidad de Antioquia, El Ministerio; 2015. Está.

Moore R., Tzipori S., Griffiths JK., Johnson K., de Montigny L., Lomakina I. 1995. Temporal changes in permeability and structure of piglet ileum after site-specific infection by cryptosporidium parvum. Gastroenterology 108:1030-1039. DOI: 
Morgan XC., Huttenhower C. 2014. Meta'omic analytic techniques for studying the intestinal microbiome. Gastroenterology 146. DOI: 10.1053/j.gastro.2014.01.049. Naghavi M., Wang H., Lozano R., Davis A., Liang X., Zhou M., Vollset SE., Abbasoglu Ozgoren A., Abdalla S., Abd-Allah F., Abdel Aziz MI., Abera SF., Aboyans V., Abraham B., Abraham JP., Abuabara KE., Abubakar I., Abu-Raddad LJ., AbuRmeileh NME., Achoki T., Adelekan A., Ademi Z., Adofo K., Adou AK., Adsuar JC., Ärnlov J., Agardh EE., Akena D., Al Khabouri MJ., Alasfoor D., Albittar M., Alegretti MA., Aleman A V., Alemu ZA., Alfonso-Cristancho R., Alhabib S., Ali MK., Ali R., Alla F., Al Lami F., Allebeck P., AlMazroa MA., Al-Shahi Salman R., Alsharif U., Alvarez E., Alviz-Guzman N., Amankwaa AA., Amare AT., Ameli O., Amini H., Ammar W., Anderson HR., Anderson BO., Antonio CAT., Anwari P., Apfel H., Argeseanu Cunningham S., Arsic Arsenijevic VS., Artaman A., Asad MM., Asghar RJ., Assadi R., Atkins LS., Atkinson C., Badawi A., Bahit MC., Bakfalouni T., Balakrishnan K., Balalla S., Banerjee A., Barber RM., Barker-Collo SL., Barquera S., Barregard L., Barrero LH., Barrientos-Gutierrez T., Basu A., Basu S., Basulaiman MO., Beardsley J., Bedi N., Beghi E., Bekele T., Bell ML., Benjet C., Bennett DA., Bensenor IM., Benzian H., Bertozzi-Villa A., Beyene TJ., Bhala N., Bhalla A., Bhutta ZA., Bikbov B., Bin Abdulhak A., Biryukov S., Blore JD., Blyth FM., Bohensky MA., Borges G., Bose D., Boufous S., Bourne RR., Boyers LN., Brainin M., Brauer M., Brayne CEG., Brazinova A., Breitborde N., Brenner H., Briggs ADM., Brown JC., Brugha TS., Buckle GC., Bui LN., Bukhman G., Burch M., Campos Nonato IR., Carabin H., Cárdenas R., Carapetis J., Carpenter DO., Caso V., Castañeda-Orjuela CA., Castro RE., Catalá-López F., Cavalleri F., Chang JC., Charlson FC., Che X., Chen H., Chen Y., Chen JS., Chen Z., Chiang PPC., Chimed-Ochir O., Chowdhury R., Christensen H., Christophi CA., Chuang TW., Chugh SS., Cirillo M., Coates MM., Coffeng LE., Coggeshall MS., Cohen A., Colistro V., Colquhoun SM., Colomar M., Cooper LT., Cooper C., Coppola LM., Cortinovis M., Courville K., Cowie BC., Criqui MH., Crump JA., Cuevas-Nasu L., Da Costa Leite I., Dabhadkar KC., Dandona L., Dandona R., Dansereau E., Dargan PI., Dayama A., De La Cruz-Góngora V., De La Vega SF., De Leo D., Degenhardt 
707 L., Del Pozo-Cruz B., Dellavalle RP., Deribe K., Des Jarlais DC., Dessalegn M., De

708

709

710

711

712

713

714

715

716

717

718

719

720

721

722

723

724

725

726

727

728

729

730

731

732

733

734

735

736

737 Veber GA., Dharmaratne SD., Dherani M., Diaz-Ortega JL., Diaz-Torne C., Dicker D., Ding EL., Dokova K., Dorsey ER., Driscoll TR., Duan L., Duber HC., Durrani AM., Ebel BE., Edmond KM., Ellenbogen RG., Elshrek Y., Ermakov SP., Erskine HE., Eshrati B., Esteghamati A., Estep K., Fürst T., Fahimi S., Fahrion AS., Faraon EJA., Farzadfar F., Fay DFJ., Feigl AB., Feigin VL., Felicio MM., Fereshtehnejad SM., Fernandes JG., Ferrari AJ., Fleming TD., Foigt N., Foreman K., Forouzanfar MH., Fowkes FGR., Fra Paleo U., Franklin RC., Futran ND., Gaffikin L., Gambashidze K., Gankpé FG., García-Guerra FA., Garcia AC., Geleijnse JM., Gessner BD., Gibney KB., Gillum RF., Gilmour S., Ginawi IAM., Giroud M., Glaser EL., Goenka S., Gomez Dantes H., Gona P., Gonzalez-Medina D., Guinovart C., Gupta R., Gupta R., Gosselin RA., Gotay CC., Goto A., Gouda HN., Graetz N., Greenwell KF., Gugnani HC., Gunnell D., Gutiérrez RA., Haagsma J., Hafezi-Nejad N., Hagan H., Hagstromer M., Halasa YA., Hamadeh RR., Hamavid H., Hammami M., Hancock J., Hankey GJ., Hansen GM., Harb HL., Harewood H., Haro JM., Havmoeller R., Hay RJ., Hay SI., Hedayati MT., Heredia Pi IB., Heuton KR., Heydarpour P., Higashi H., Hijar M., Hoek HW., Hoffman HJ., Hornberger JC., Hosgood HD., Hossain M., Hotez PJ., Hoy DG., Hsairi M., Hu G., Huang JJ., Huffman MD., Hughes AJ., Husseini A., Huynh C., lannarone M., Iburg KM., Idrisov BT., Ikeda N., Innos K., Inoue M., Islami F., Ismayilova S., Jacobsen KH., Jassal S., Jayaraman SP., Jensen PN., Jha V., Jiang G., Jiang Y., Jonas JB., Joseph J., Juel K., Kabagambe EK., Kan H., Karch A., Karimkhani C., Karthikeyan G., Kassebaum N., Kaul A., Kawakami N., Kazanjan K., Kazi DS., Kemp AH., Kengne AP., Keren A., Kereselidze M., Khader YS., Khalifa SEAH., Khan EA., Khan G., Khang YH., Kieling C., Kinfu Y., Kinge JM., Kim D., Kim S., Kivipelto M., Knibbs L., Knudsen AK., Kokubo Y., Kosen S., Kotagal M., Kravchenko MA., Krishnaswami S., Krueger H., Kuate Defo B., Kuipers EJ., Kucuk Bicer B., Kulkarni C., Kulkarni VS., Kumar K., Kumar RB., Kwan GF., Kyu H., Lai T., Lakshmana Balaji A., Lalloo R., Lallukka T., Lam H., Lan Q., Lansingh VC., Larson HJ., Larsson A., Lavados PM., Lawrynowicz AEB., Leasher JL., Lee JT., Leigh J., Leinsalu M., Leung R., Levitz C., Li B., Li Y., Li Y., Liddell C., Lim SS., De Lima GMF., Lind ML., Lipshultz 
SE., Liu S., Liu Y., Lloyd BK., Lofgren KT., Logroscino G., London SJ., LortetTieulent J., Lotufo PA., Lucas RM., Lunevicius R., Lyons RA., Ma S., Machado VMP., Maclntyre MF., Mackay MT., MacLachlan JH., Magis-Rodriguez C., Mahdi AA., Majdan M., Malekzadeh R., Mangalam S., Mapoma CC., Marape M., Marcenes W., Margono C., Marks GB., Marzan MB., Masci JR., Mashal MT., Masiye F., Mason-Jones AJ., Matzopolous R., Mayosi BM., Mazorodze TT., McGrath JJ., McKay AC., McKee M., McLain A., Meaney PA., Mehndiratta MM., Mejia-Rodriguez F., Melaku YA., Meltzer M., Memish ZA., Mendoza W., Mensah GA., Meretoja A., Mhimbira FA., Miller TR., Mills EJ., Misganaw A., Mishra SK., Mock CN., Moffitt TE., Mohamed Ibrahim N., Mohammad KA., Mokdad AH., Mola GL., Monasta L., Monis JDLC., Montañez Hernandez JC., Montico M., Montine TJ., Mooney MD., Moore AR., Moradi-Lakeh M., Moran AE., Mori R., Moschandreas J., Moturi WN., Moyer ML., Mozaffarian D., Mueller UO., Mukaigawara M., Mullany EC., Murray J., Mustapha A., Naghavi P., Naheed A., Naidoo KS., Naldi L., Nand D., Nangia V., Narayan KMV., Nash D., Nasher J., Nejjari C., Nelson RG., Neuhouser M., Neupane SP., Newcomb PA., Newman L., Newton CR., Ng M., Ngalesoni FN., Nguyen G., Nguyen NTT., Nisar MI., Nolte S., Norheim OF., Norman RE., Norrving B., Nyakarahuka L., Odell S., O’Donnell M., Ohkubo T., Ohno SL., Olusanya BO., Omer SB., Opio JN., Orisakwe OE., Ortblad KF., Ortiz A., Otayza MLK., Pain AW., Pandian JD., Panelo Cl., Panniyammakal J., Papachristou C., Paternina Caicedo AJ., Patten SB., Patton GC., Paul VK., Pavlin B., Pearce N., Pellegrini CA., Pereira DM., Peresson SC., Perez-Padilla R., Perez-Ruiz FP., Perico N., Pervaiz A., Pesudovs K., Peterson CB., Petzold M., Phillips BK., Phillips DE., Phillips MR., Plass D., Piel FB., Poenaru D., Polinder S., Popova S., Poulton RG., Pourmalek F., Prabhakaran D., Qato D., Quezada AD., Quistberg DA., Rabito F., Rafay A., Rahimi K., Rahimi-Movaghar V., Rahman SUR., Raju M., Rakovac I., Rana SM., Refaat A., Remuzzi G., Ribeiro AL., Ricci S., Riccio PM., Richardson L., Richardus JH., Roberts B., Roberts DA., Robinson M., Roca A., Rodriguez A., Rojas-Rueda D., Ronfani L., Room R., Roth GA., Rothenbacher D., Rothstein DH., Rowley JTF., Roy N., Ruhago GM., Rushton L., Sambandam S., Søreide K., Saeedi MY., Saha S., Sahathevan R., Sahraian MA., Sahle BW., Salomon JA., 
Salvo D., Samonte GMJ., Sampson U., Sanabria JR., Sandar L., Santos IS., Satpathy M., Sawhney M., Saylan M., Scarborough P., Schöttker B., Schmidt JC., Schneider IJC., Schumacher AE., Schwebel DC., Scott JG., Sepanlou SG., Servan-Mori EE., Shackelford K., Shaheen A., Shahraz S., Shakh-Nazarova M., Shangguan S., She J., Sheikhbahaei S., Shepard DS., Shibuya K., Shinohara Y., Shishani K., Shiue I., Shivakoti R., Shrime MG., Sigfusdottir ID., Silberberg DH., Silva AP., Simard EP., Sindi S., Singh JA., Singh L., Sioson E., Skirbekk V., Sliwa K., So S., Soljak M., Soneji S., Soshnikov SS., Sposato LA., Sreeramareddy CT., Stanaway JD., Stathopoulou VK., Steenland K., Stein C., Steiner C., Stevens A., Stöckl H., Straif K., Stroumpoulis K., Sturua L., Sunguya BF., Swaminathan S., Swaroop M., Sykes BL., Tabb KM., Takahashi K., Talongwa RT., Tan F., Tanne D., Tanner M., Tavakkoli M., Te Ao B., Teixeira CM., Templin T., Tenkorang EY., Terkawi AS., Thomas BA., Thorne-Lyman AL., Thrift AG., Thurston GD., Tillmann T., Tirschwell DL., Tleyjeh IM., Tonelli M., Topouzis F., Towbin JA., Toyoshima H., Traebert J., Tran BX., Truelsen T., Trujillo U., Trillini M., Tsala Dimbuene Z., Tsilimbaris M., Tuzcu EM., Ubeda C., Uchendu US., Ukwaja KN., Undurraga EA., Vallely AJ., Van De Vijver S., Van Gool CH., Varakin YY., Vasankari TJ., Vasconcelos AMN., Vavilala MS., Venketasubramanian N., Vijayakumar L., Villalpando S., Violante FS., Vlassov VV., Wagner GR., Waller SG., Wang JL., Wang L., Wang XR., Wang Y., Warouw TS., Weichenthal S., Weiderpass E., Weintraub RG., Wenzhi W., Werdecker A., Wessells KRR., Westerman R., Whiteford HA., Wilkinson JD., Williams TN., Woldeyohannes SM., Wolfe CDA., Wolock TM., Woolf AD., Wong JQ., Wright JL., Wulf S., Wurtz B., Xu G., Yang YC., Yano Y., Yatsuya H., Yip P., Yonemoto N., Yoon SJ., Younis M., Yu C., Yun Jin K., Zaki MES., Zamakhshary MF., Zeeb H., Zhang Y., Zhao Y., Zheng Y., Zhu J., Zhu S., Zonies D., Zou XN., Zunt JR., Vos T., Lopez AD., Murray CJL., Alcalá-Cerra G., Hu H., Karam N., Sabin N., Temesgen AM. 2015. Global, regional, and national age-sex specific all-cause and cause-specific mortality for 240 causes of death, 1990-2013: A systematic analysis for the Global Burden of Disease Study 2013. The Lancet 385:117-171. DOI: 10.1016/S0140-6736(14)61682-2.

O'Callaghan A., van Sinderen D. 2016. Bifidobacteria and their role as members of the 
800

801

802

803

804

805

806

807

808

809

810

811

812

813

814

815

816

817

818

819

820

821

822

823

824

825

826

827

828

829

human gut microbiota. Frontiers in Microbiology 7. DOI: 10.3389/fmicb.2016.00925.

Odamaki T., Kato K., Sugahara H., Hashikura N., Takahashi S., Xiao JZ., Abe F., Osawa R. 2016. Age-related changes in gut microbiota composition from newborn to centenarian: A cross-sectional study. BMC Microbiology 16:1-12. DOI: 10.1186/s12866-016-0708-5.

Ou J., Carbonero F., Zoetendal EG., DeLany JP., Wang M., Newton K., Gaskins HR., O'Keefe SJD. 2013. Diet, microbiota, and microbial metabolites in colon cancer risk in rural Africans and African Americans. American Journal of Clinical Nutrition 98:111-120. DOI: 10.3945/ajcn.112.056689.

Parfrey LW., Jirků M., Šíma R., Jalovecká M., Sak B., Grigore K., Pomajbíková KJ. 2017. A benign helminth alters the host immune system and the gut microbiota in a rat model system. PLOS ONE 12:1-22. DOI: 10.1371/journal.pone.0182205.

Peterson LW., Artis D. 2014. Intestinal epithelial cells: Regulators of barrier function and immune homeostasis. Nature Reviews Immunology 14:141-153. DOI: 10.1038/nri3608.

Petrof EO., Gloor GB., Vanner SJ., Weese SJ., Carter D., Daigneault MC., Brown EM., Schroeter K., Allen-Vercoe E. 2013. Stool substitute transplant therapy for the eradication of Clostridium difficile infection: "RePOOPulating" the gut. Microbiome 1:1-12. DOI: 10.1186/2049-2618-1-3.

Platts-Mills JA., Babji S., Bodhidatta L., Gratz J., Haque R., Havt A., McCormick BJJ., McGrath M., Olortegui MP., Samie A., Shakoor S., Mondal D., Lima IFN., Hariraju D., Rayamajhi BB., Qureshi S., Kabir F., Yori PP., Mufamadi B., Amour C., Carreon JD., Richard SA., Lang D., Bessong P., Mduma E., Ahmed T., Lima AAAM., Mason CJ., Zaidi AKM., Bhutta ZA., Kosek M., Guerrant RL., Gottlieb M., Miller M., Kang G., Houpt ER., Chavez CB., Trigoso DR., Flores JT., Vasquez AO., Pinedo SR., Acosta AM., Ahmed I., Alam D., Ali A., Rasheed M., Soofi S., Turab A., Yousafzai AK., Bose A., Jennifer MS., John S., Kaki S., Koshy B., Muliyil J., Raghava MV., Ramachandran A., Rose A., Sharma SL., Thomas RJ., Pan W., Ambikapathi R., Charu V., Dabo L., Doan V., Graham J., Hoest C., Knobler S., Mohale A., Nayyar G., Psaki S., Rasmussen Z., Seidman JC., Wang V., Blank R., Tountas KH., 
830

831

832

833

834

835

836

837

838

839

840

841

842

843

844

845

846

847

848

849

850

851

852

853

854

855

856

857

858

859

Swema BM., Yarrot L., Nshama R., Ahmed AMS., Tofail F., Hossain I., Islam M., Mahfuz M., Chandyo RK., Shrestha PS., Shrestha R., Ulak M., Black R., Caulfield L., Checkley W., Chen P., Lee G., Murray-Kolb LE., Schaefer B., Pendergast L., Abreu C., Costa H., Moura A Di., Filho JQ., Leite Á., Lima N., Maciel B., Moraes M., Mota F., Oriá R., Quetz J., Soares A., Patil CL., Mahopo C., Mapula A., Nesamvuni C., Nyathi E., Barrett L., Petri WA., Scharf R., Shrestha B., Shrestha SK., Strand T., Svensen E. 2015. Pathogen-specific burdens of community diarrhoea in developing countries: A multisite birth cohort study (MAL-ED). The Lancet Global Health 3:e564-e575. DOI: 10.1016/S2214-109X(15)00151-5.

Ras R., Huynh K., Desoky E., Badawy A., Widmer G. 2015. Perturbation of the intestinal microbiota of mice infected with Cryptosporidium parvum. International Journal for Parasitology 45:567-573. DOI: 10.1016/J.IJPARA.2015.03.005.

Resende Co T., Hirsch CS., Toossi Z., Dietze R., Ribeiro-Rodrigues R. 2007. Intestinal helminth co-infection has a negative impact on both anti-Mycobacterium tuberculosis immunity and clinical response to tuberculosis therapy. Clinical and Experimental Immunology 147:45-52. DOI: 10.1111/j.1365-2249.2006.03247.x.

Reynolds LA., Finlay BB., Maizels RM. 2015. Cohabitation in the Intestine: Interactions among Helminth Parasites, Bacterial Microbiota, and Host Immunity. The Journal of Immunology 195:4059-4066. DOI: 10.4049/jimmunol.1501432.

Roager HM., Licht TR., Poulsen SK., Larsen TM., Bahl MI. 2014. Microbial enterotypes, inferred by the Prevotella-to-Bacteroides ratio, remained stable during a 6-month randomized controlled diet intervention with the new nordic diet. Applied and Environmental Microbiology 80:1142-1149. DOI: 10.1128/AEM.03549-13.

Schloss PD., Westcott SL., Ryabin T., Hall JR., Hartmann M., Hollister EB., Lesniewski RA., Oakley BB., Parks DH., Robinson CJ., Sahl JW., Stres B., Thallinger GG., Van Horn DJ., Weber CF. 2009. Introducing mothur: Open-source, platformindependent, community-supported software for describing and comparing microbial communities. Applied and Environmental Microbiology. DOI: 10.1128/AEM.01541-09.

Segata N. 2015. Gut Microbiome: Westernization and the Disappearance of Intestinal 
Diversity. Current biology : CB 25:R611-3. DOI: 10.1016/j.cub.2015.05.040.

861

862

863

864

865

866

867

868

869

870

871

872

873

874

875

876

Selby W., Pavli P., Crotty B., Florin T., Radford-Smith G., Gibson P., Mitchell B., Connell W., Read R., Merrett M., Ee H., Hetzel D. 2007. Two-Year Combination Antibiotic Therapy With Clarithromycin, Rifabutin, and Clofazimine for Crohn's Disease. Gastroenterology 132:2313-2319. DOI: 10.1053/j.gastro.2007.03.031.

Sellon RK., Tonkonogy S., Schultz M., Dieleman LA., Grenther W., Balish E., Rennick DM., Sartor RB. 1998. Resident enteric bacteria are necessary for development of spontaneous colitis and immune system activation in interleukin-10-deficient mice. Infection and Immunity 66:5224-5231.

Sipahi AM., Baptista DM. 2017. Helminths as an alternative therapy for intestinal diseases. World journal of gastroenterology 23:6009-6015. DOI: 10.3748/wjg.v23.i33.6009.

Syal G., Kashani A., Shih DQ. 2018. Fecal Microbiota Transplantation in Inflammatory Bowel Disease- a Primer for the Internists. The American Journal of Medicine. DOI: 10.1016/j.amjmed.2018.03.010.

Tamanai-Shacoori Z., Smida I., Bousarghin L., Loreal O., Meuric V., Fong SB., Bonnaure-Mallet M., Jolivet-Gougeon A. 2017. Roseburia spp.: a marker of health? Future microbiology 12:157-170. DOI: 10.2217/fmb-2016-0130.

Ubeda C., Djukovic A., Isaac S. 2017. Roles of the intestinal microbiota in pathogen protection. Clinical \& Translational Immunology 6:e128. DOI: 10.1038/cti.2017.2.

Ubeda C., Pamer EG. 2012. Antibiotics, microbiota, and immune defense. Trends in Immunology 33:459-466. DOI: 10.1016/j.it.2012.05.003.

Wang Y., Xu L., Gu YQ., Coleman-Derr D. 2016. MetaCoMET: A web platform for discovery and visualization of the core microbiome. Bioinformatics. DOI: 10.1093/bioinformatics/btw507.

Wu GD., Chen J., Hoffmann C., Bittinger K., Chen Y., Keilbaugh SA., Bewtra M., Knights D., Walters WA., Knight R., Sinha R., Gilroy E., Gupta K., Baldassano R., Nessel L., Li H., Bushman FD., Lewis JD. 2011. Linking long-term dietary patterns with gut microbial enterotypes. Science (New York, N.Y.) 334:105-8. DOI: 10.1126/science.1208344. 
890 Xiao L., Escalante L., Yang C., Sulaiman I., Escalante a a., Montali RJ., Fayer R., Lal 891 a a. 1999. Phylogenetic analysis of Cryptosporidium parasites based on the small892 subunit rRNA gene locus. Applied and environmental microbiology 65:1578-83.

893 Xiao L., Singh A., Limor J., Graczyk TK., Gradus S., Lal A. 2001. Molecular

894 characterization of cryptosporidium oocysts in samples of raw surface water and

895 wastewater. Applied and environmental microbiology 67:1097-101. DOI:

896 10.1128/AEM.67.3.1097-1101.2001.

897 Yatsunenko T., Rey FE., Manary MJ., Trehan I., Dominguez-Bello MG., Contreras M., 898 Magris M., Hidalgo G., Baldassano RN., Anokhin AP., Heath AC., Warner B., 899 Reeder J., Kuczynski J., Caporaso JG., Lozupone CA., Lauber C., Clemente JC., 900 Knights D., Knight R., Gordon Jl. 2012. Human gut microbiome viewed across age 901 902 903 Yin Y., Fan B., Liu W., Ren R., Chen H., Bai S., Zhu L., Sun G., Yang Y., Wang X. 2017. Investigation into the stability and culturability of Chinese enterotypes.

904 Scientific Reports 7:7947. DOI: 10.1038/s41598-017-08478-w.

905

906

907 


\section{Table $\mathbf{1}$ (on next page)}

Description of samples used in this study.

Different features like origin of the sample, age and sex, along with the different parasites found in each sample, are indicated. 


\begin{tabular}{|c|c|c|c|c|c|}
\hline Care-centers & Group & Sample & Sex & Age & $\begin{array}{l}\text { Parasites Observed by } \\
\text { Microscopy or PCR }\end{array}$ \\
\hline \multirow{3}{*}{ Care-center 1} & Helm-Pro & CD13 & $\mathrm{F}$ & 5 & $\begin{array}{l}\text { Entamoeba } h / d / m \text {; Blastocystis spp; Ascaris lumbricoides; } \\
\text { Trichuris trichiura }\end{array}$ \\
\hline & Crypto & CD17 & $\mathrm{F}$ & 2 & Cryptosporidium; Blastocystis spp \\
\hline & Control & CD18 & M & 3 & none \\
\hline \multirow{14}{*}{ Care-center 2} & Giardia & ED05 & M & 2 & Giardia intestinalis \\
\hline & Crypto & ED06 & $\mathrm{F}$ & 1 & Cryptosporidium \\
\hline & Crypto & ED15 & M & 1 & Cryptosporidium; Blastocystis spp \\
\hline & Giardia & ED16 & $\mathrm{F}$ & 1 & Giardia intestinalis \\
\hline & Helm-Pro & ED17 & $\mathrm{F}$ & 2 & Blastocystis spp; Ascaris lumbricoides; Enterobius vermicularis \\
\hline & Helm-Pro & ED23 & M & 3 & $\begin{array}{l}\text { Giardia lamblia; Chilomastix mesnilii; Ascaris lumbricoides; } \\
\text { Trichuris trichiura }\end{array}$ \\
\hline & Control & ED29 & $\mathrm{F}$ & 2 & none \\
\hline & Crypto & ED33 & $\mathrm{F}$ & 1 & Cryptosporidium \\
\hline & Control & ED36 & $\mathrm{F}$ & 4 & none \\
\hline & Giardia & ED47 & $\mathrm{F}$ & 3 & Giardia intestinalis \\
\hline & Giardia & ED54 & $F$ & 4 & Giardia intestinalis \\
\hline & Helm-Pro & ED69 & $\mathrm{F}$ & 5 & $\begin{array}{l}\text { Entamoeba hartmanni; Giardia intestinalis; Blastocystis spp; } \\
\text { Ascaris lumbricoides }\end{array}$ \\
\hline & Giardia & ED77 & $\mathrm{M}$ & 3 & Giardia intestinalis \\
\hline & Crypto & ED9 & M & 1 & Cryptosporidium \\
\hline \multirow{4}{*}{ Care-center 3} & Control & ES02 & $\mathrm{M}$ & 5 & none \\
\hline & Giardia & ES04 & N.A & N.A & Giardia intestinalis \\
\hline & Control & ES05 & $\mathrm{M}$ & 3 & none \\
\hline & Control & ES07 & $M$ & 5 & none \\
\hline \multirow{2}{*}{ Care-center 4} & Helm-Pro & SE23 & $\mathrm{F}$ & 4 & Blastocystis spp.; Ascaris lumbricoides; Trichuris trichiura \\
\hline & Helm-Pro & SE56 & M & 4 & Giardia intestinalis; Ascaris lumbricoides; Trichuris trichiura \\
\hline
\end{tabular}


Table 2 (on next page)

Statistical diversity of the individuals surveyed in the study. 


\begin{tabular}{|c|c|c|c|c|c|c|}
\hline Sample & $\begin{array}{c}\text { Number of } \\
\text { Sequences }\end{array}$ & Coverage & OTUs & $\begin{array}{c}\text { Simpson } \\
\text { Index }\end{array}$ & $\begin{array}{c}\text { Shannon } \\
\text { Index }\end{array}$ & CHAO Index \\
\hline ES02 & 3319 & 0.983 & 162 & 16.214 & 3.554 & 228.500 \\
\hline ED36 & 9125 & 0.992 & 199 & 9.971 & 3.060 & 325.136 \\
\hline CD18 & 6949 & 0.992 & 152 & 15.401 & 3.247 & 251.750 \\
\hline ES04 & 5652 & 0.992 & 126 & 4.231 & 2.320 & 180.474 \\
\hline ED54 & 7722 & 0.992 & 171 & 7.270 & 2.968 & 318.500 \\
\hline ED47 & 6339 & 0.993 & 160 & 15.064 & 3.508 & 217.400 \\
\hline ED69 & 17814 & 0.994 & 343 & 5.511 & 3.081 & 490.163 \\
\hline ED17 & 13114 & 0.994 & 220 & 12.430 & 3.340 & 382.048 \\
\hline ED16 & 8427 & 0.994 & 164 & 5.556 & 2.936 & 246.875 \\
\hline CD13 & 18735 & 0.995 & 229 & 2.367 & 1.950 & 419.120 \\
\hline ED06 & 15928 & 0.995 & 221 & 22.718 & 3.599 & 395.789 \\
\hline ED23 & 20283 & 0.995 & 257 & 9.080 & 3.095 & 512.316 \\
\hline SE23 & 19904 & 0.995 & 262 & 4.362 & 2.455 & 400.182 \\
\hline ES07 & 13312 & 0.995 & 224 & 16.021 & 3.435 & 324.800 \\
\hline ED05 & 5472 & 0.995 & 95 & 6.351 & 2.518 & 124.545 \\
\hline ED15 & 18153 & 0.996 & 177 & 4.207 & 2.495 & 420.077 \\
\hline ES05 & 18545 & 0.996 & 215 & 10.020 & 3.124 & 335.120 \\
\hline ED77 & 17978 & 0.996 & 212 & 6.857 & 3.002 & 336.250 \\
\hline CD17 & 22208 & 0.996 & 201 & 3.580 & 2.270 & 329.375 \\
\hline SE56 & 57133 & 0.997 & 360 & 4.276 & 2.276 & 901.750 \\
\hline ED9 & 20140 & 0.997 & 153 & 15.584 & 3.326 & 354.600 \\
\hline ED29 & 20649 & 0.997 & 150 & 9.368 & 2.713 & 294.000 \\
\hline ED33 & 10385 & 0.998 & 70 & 6.552 & 2.436 & 100.000 \\
\hline & & & & & & \\
\hline
\end{tabular}




\section{Figure 1 (on next page)}

Figure 1 | Box-plot comparisons of bacterial diversity and species richness.

(A) Bacterial diversity of the different groups using Shannon's alpha index and (B) Species Richness found in the same groups. The top and bottom boundaries of each box indicate the 75th and 25th quartile values, respectively, and lines within each box represent the 50th quartile (median) values. Ends of whiskers mark the lowest and highest diversity values in each group. Though a difference in the Shannon index was expected between infected and not-infected individuals, the evenness observed can be attributable to the age of the children. Interestingly enough, the group with helminths and protozoa showed the highest number of bacterial species. 
A.

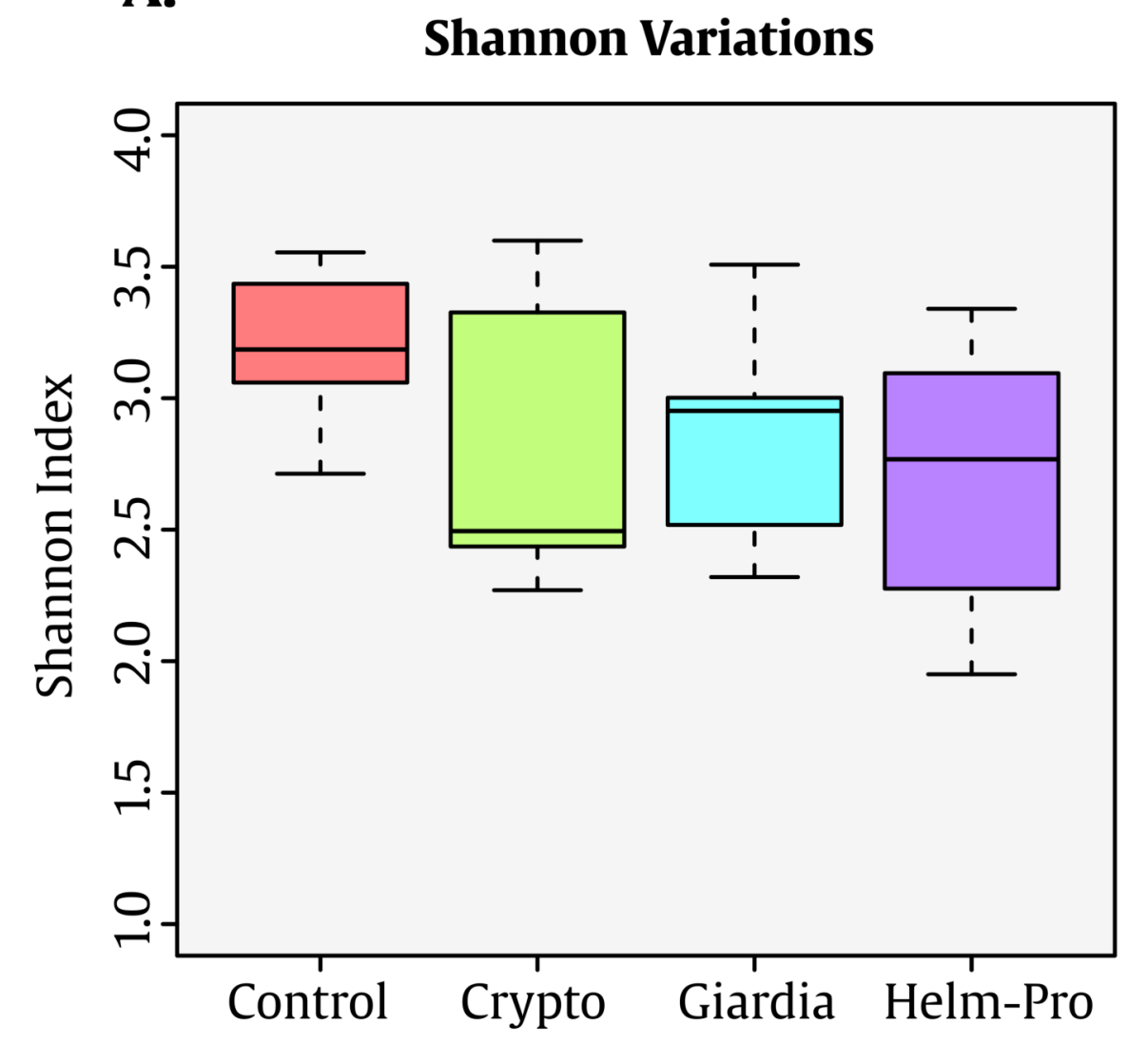

B.

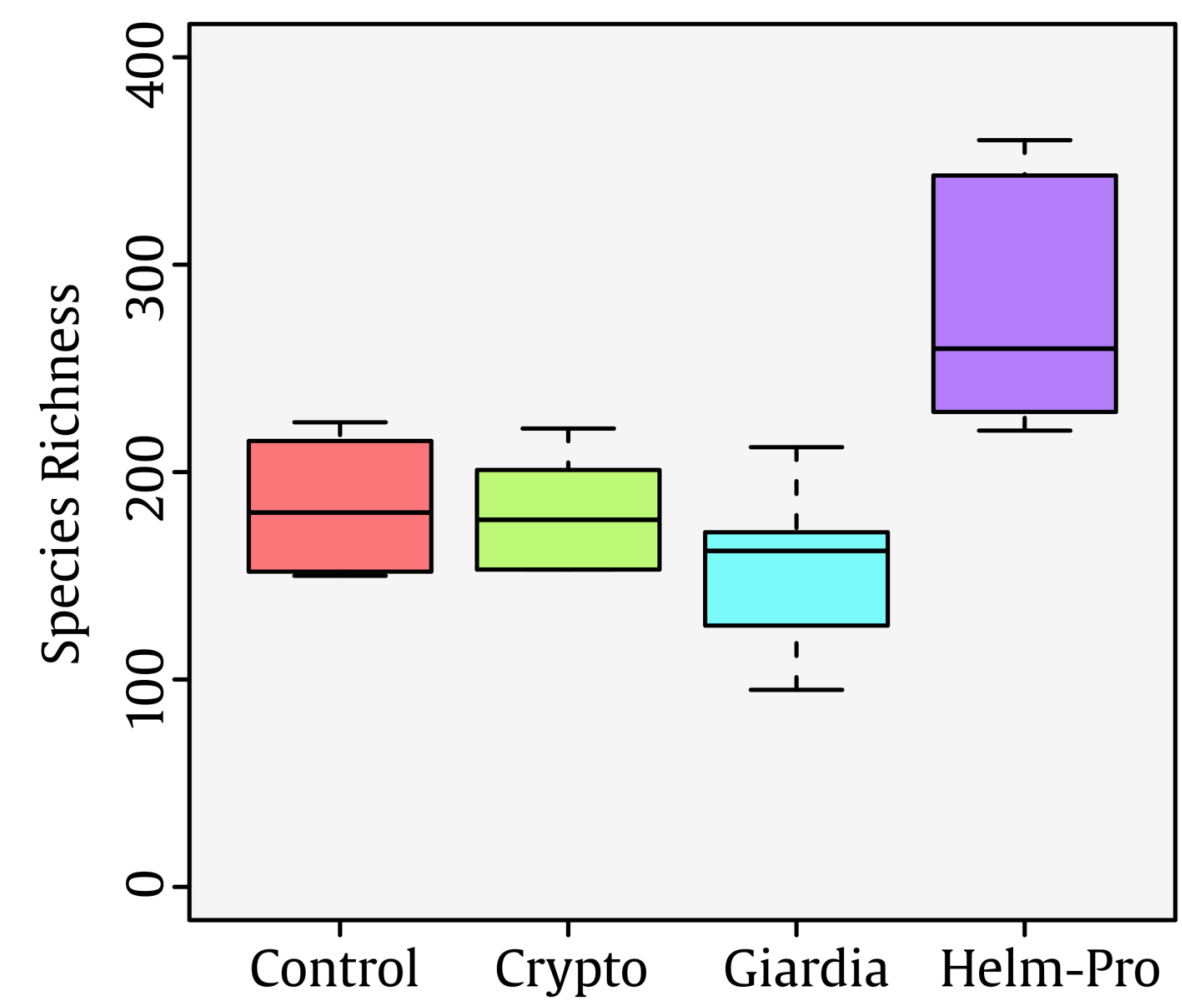




\section{Figure 2}

Figure 2 | Bacterial gut microbiota comparison at Genera level per group.

A switch from enterotype I enriched in Bacteroides spp. in the control individuals to enterotype II enriched with Prevotella spp. in the Helm-Pro and Giardia groups is noticeable, suggesting a change of enterotype upon parasite infection. The families are shown in bold and the genera in italics. 


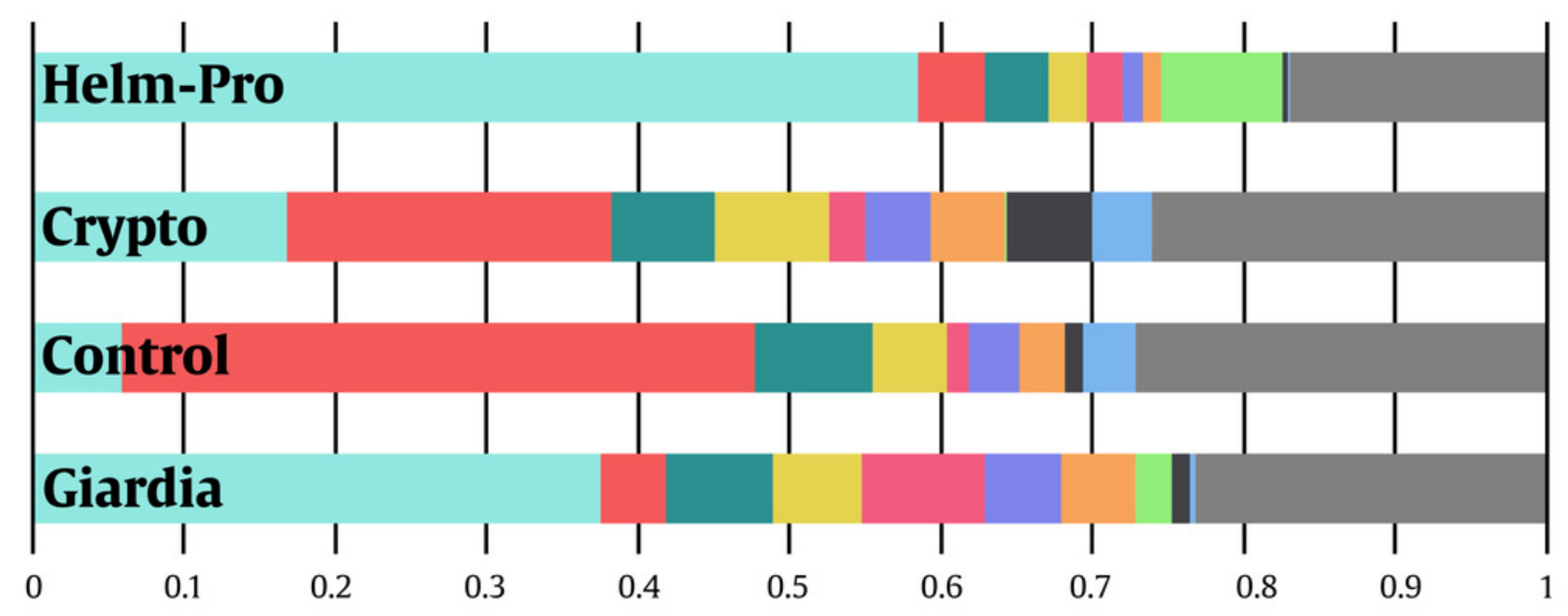

Composition of taxonomy

Bacteria;Bacteroidetes;Bacteroidia;Bacteroidales;Prevotellaceae;Prevotella

Bacteria;Bacteroidetes;Bacteroidia;Bacteroidales;Bacteroidaceae;Bacteroides

Bacteria;Firmicutes;Clostridia;Clostridiales;Ruminococcaceae;Faecalibacterium

Bacteria;Firmicutes;Clostridia;Clostridiales;Lachnospiraceae;Lachnospiraceae_unclassified

Bacteria;Firmicutes;Clostridia;Clostridiales;Lachnospiraceae;Roseburia

Bacteria;Firmicutes;Clostridia;Clostridiales; Ruminococcaceae; Ruminococcaceae_unclassified

Bacteria;Firmicutes;Negativicutes;Selenomonadales;Veillonellaceae;Veillonella

Bacteria;Bacteroidetes;Bacteroidia;Bacteroidales;Prevotellaceae;Alloprevotella

Bacteria;Actinobacteria;Actinobacteria;Bifidobacteriales;Bifidobacteriaceae;Bifidobacterium

Bacteria;Bacteroidetes;Bacteroidia;Bacteroidales; Rikenellaceae;Alistipes

Others 


\section{Figure 3}

Figure 3 | Bacterial gut microbiota comparison at Family and Genera levels per child.

Relative abundances and richness at individual resolution. An evident enrichment of the Prevotellaceae family in ED16, ED54, ED77, ES04 individuals (Giardia group) and CD13, ED23, ED69, SE23 and SE56 individuals (Helm-Pro group) is present at expense of the Bacteroidaceae family more abundant in all the individuals of the control group. The families are shown in bold and the genera in italics. 


\section{Sequence Reads (Families)}

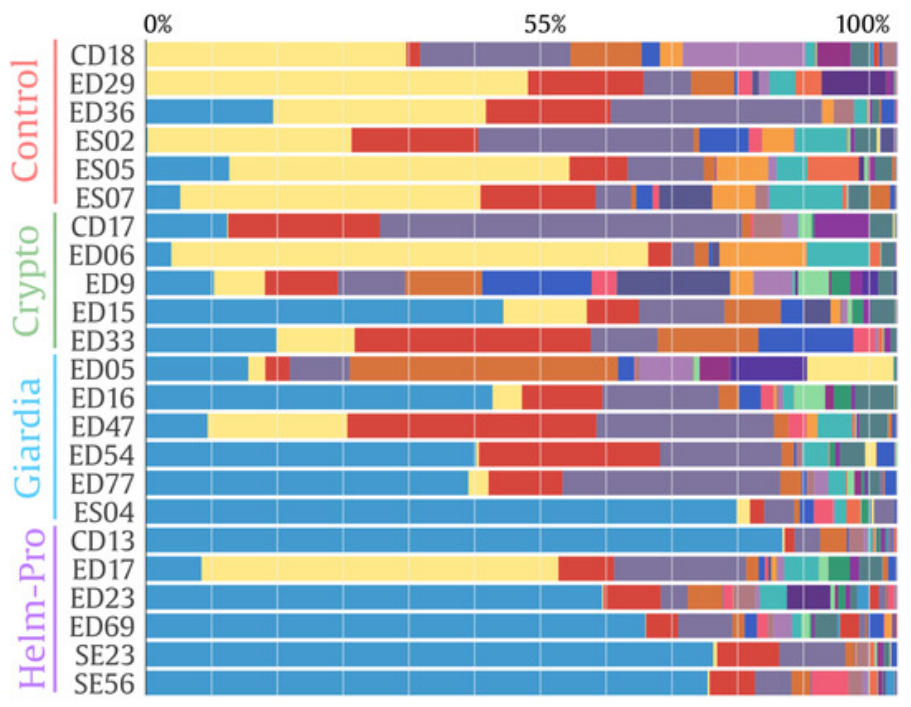

\section{Sequence Reads (Genera)}

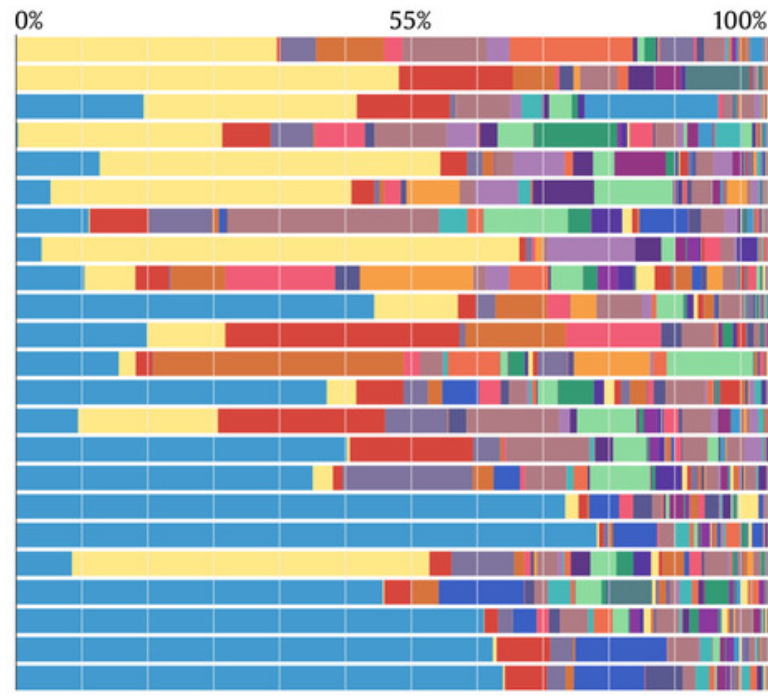

Top 10 Genera
$\ldots$... Prevotellaceae,Prevotella
$\ldots$ Bacteroidaceae,Bacteroides
$\ldots$... Ruminococcaceae,Faecalibacterium
$\ldots$... Pachnospiraceae,Lachnospiraceae_unclassified
$\ldots$... Lachnospiraceae,_Roseburia
$\ldots$ Ruminococcaceae,Ruminococcaceae_unclassified
$\ldots$... Veillonellaceae,Veillonella
$\ldots$ Bifidobacteriaceae,Bifidobacterium


Figure 4(on next page)

Figure 4 | PCoA and Venn Diagram.

(A) PCOA of the dissimilarities among bacterial communities and taxonomical structures in the control, crypto, giardia and helm-pro groups using $\theta_{r c}$ distances. There is a clustering between the individuals of the giardia group (cyan) and the helm-pro group (purple) showing that these populations are not as different as those from the control group (red). (B) Venn diagram depicting the number and OTU's distribution between the studied groups. The unique and shared OTUs of the Helm-Pro and Giardia groups could help to explain the special characteristics and structure of the parasite infected BGM. 
A.

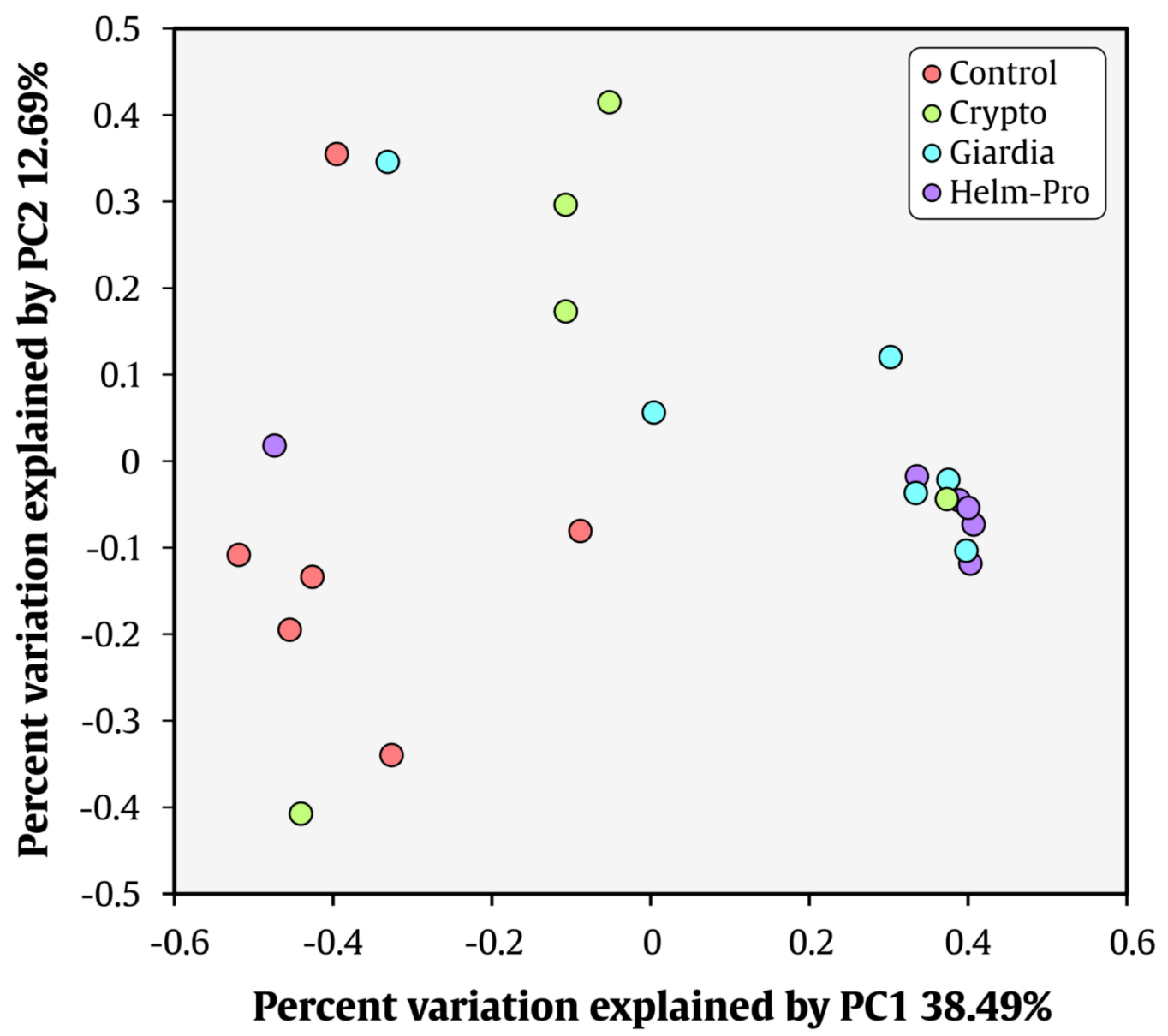

B.
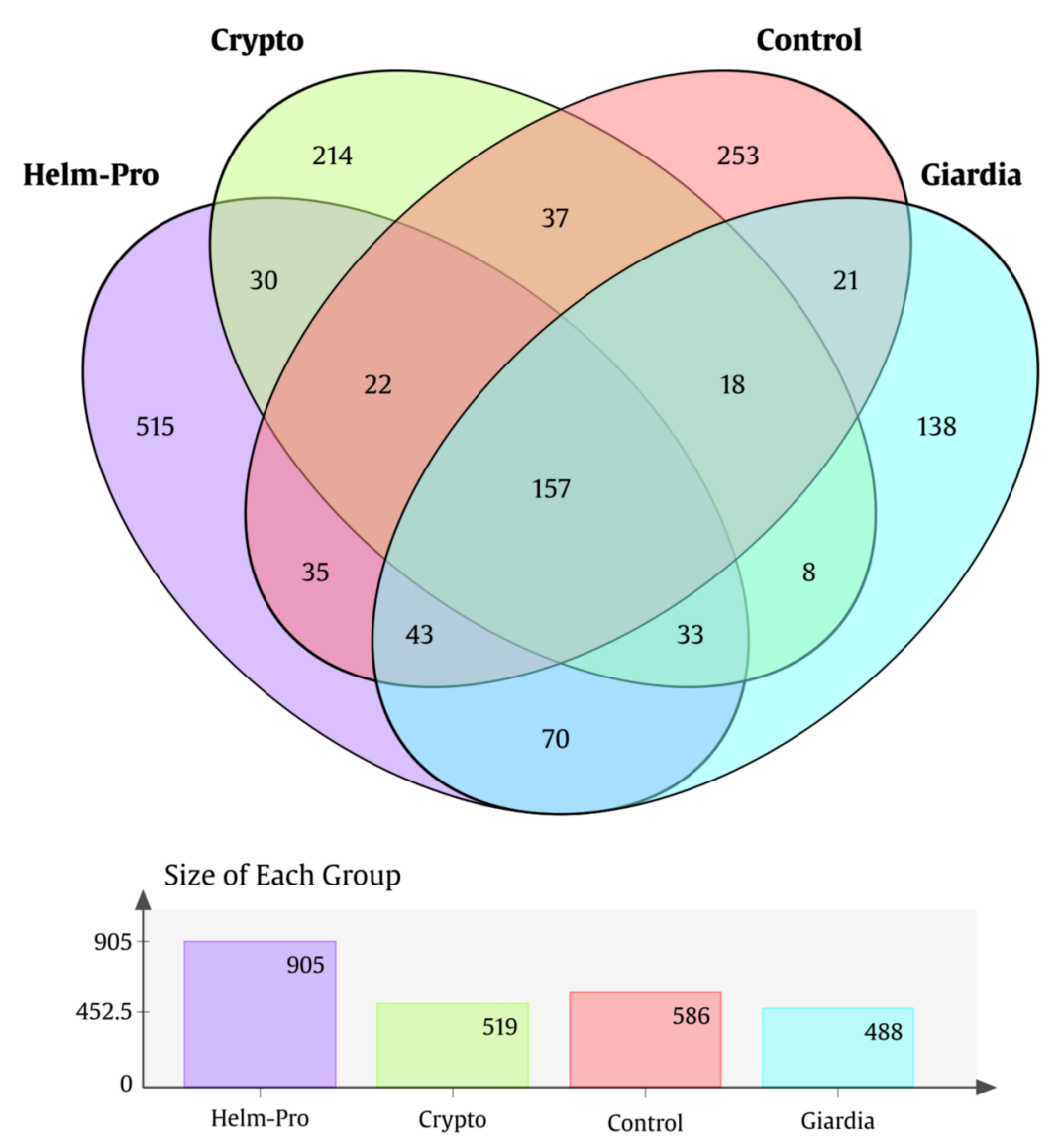


\section{Table 3(on next page)}

Treatment of the data by AMOVA analysis.

Only Control/Giardia and Control/Helm-Pro showed significant variations. 


\begin{tabular}{|c|c|c|c|c|c|c|}
\hline Hypothesis & $\begin{array}{l}\text { Source of } \\
\text { Variation }\end{array}$ & $\begin{array}{l}\text { Sum of } \\
\text { Squares }\end{array}$ & $\begin{array}{l}\text { Degrees of } \\
\text { Freedom }\end{array}$ & MS & Fs: & p-value: \\
\hline \multirow{3}{*}{ Control/Crypto } & Among & 0.47 & 1 & 0.47 & \multirow{3}{*}{1.45808} & \multirow{3}{*}{0.12} \\
\hline & Within & 2.90107 & 9 & 0.322341 & & \\
\hline & Total & 3.37107 & 10 & & & \\
\hline \multirow{3}{*}{ Control/Giardia } & Among & 1.01302 & 1 & 1.01302 & \multirow{3}{*}{4.03752} & \multirow{3}{*}{$0.006^{*}$} \\
\hline & Within & 2.50902 & 10 & 0.250902 & & \\
\hline & Total & 3.52204 & 11 & & & \\
\hline \multirow{3}{*}{ Control/Helm-pro } & Among & 1.19073 & 1 & 1.19073 & \multirow{3}{*}{5.14312} & \multirow{3}{*}{0.014} \\
\hline & Within & 2.3152 & 10 & 0.23152 & & \\
\hline & Total & 3.50593 & 11 & & & \\
\hline \multirow{3}{*}{ Crypto/Giardia } & Among & 0.298183 & 1 & 0.298183 & \multirow{3}{*}{1.02589} & \multirow{3}{*}{0.406} \\
\hline & Within & 2.61592 & 9 & 0.290658 & & \\
\hline & Total & 2.91411 & 10 & & & \\
\hline \multirow{3}{*}{ Crypto/Helm-Pro } & Among & 0.477709 & 1 & 0.477709 & \multirow{3}{*}{1.77507} & \multirow{3}{*}{0.082} \\
\hline & Within & 2.4221 & 9 & 0.269122 & & \\
\hline & Total & 2.89981 & 10 & & & \\
\hline Giardia/Helm-Pro & Among & 0.140854 & 1 & 0.140854 & 0.693847 & 0.639 \\
\hline
\end{tabular}




\section{Figure 5}

Figure 5 | Pie charts of the 3 most abundant OTUs (genera) unique and shared in Giardia and Helm-Pro groups.

(A) Shared OTUs between Helm-Pro and Giardia groups. More than 50\% of the genera observed in the shared OTUs belong to Prevotella spp., the determinant genera of the type II enterotype.(B)Unique Helm-Pro OTUs and (C)Unique Giardia OTUs. In the unique OTUs found in both, Helm-Pro and Giardia, there is a variety of anaerobic bacteria such as Fusobacterium spp., and Ruminococcus spp. 
A.

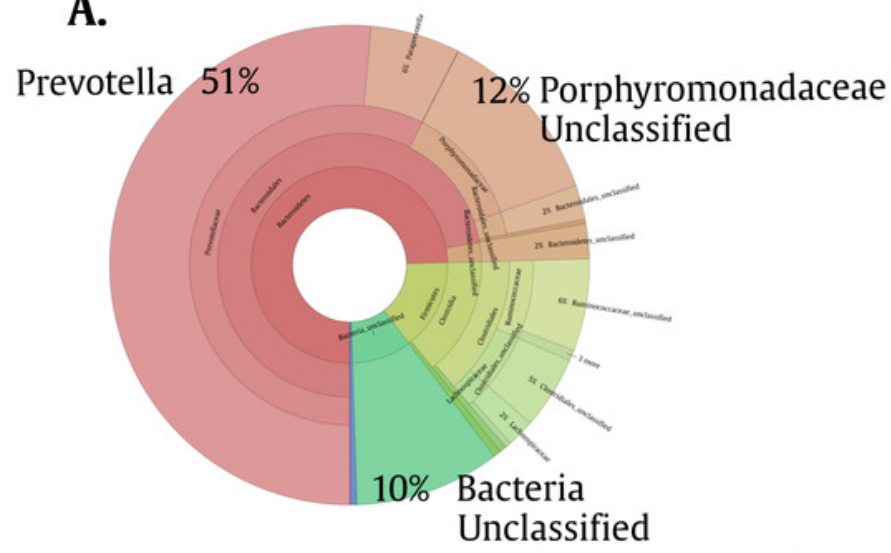

B.

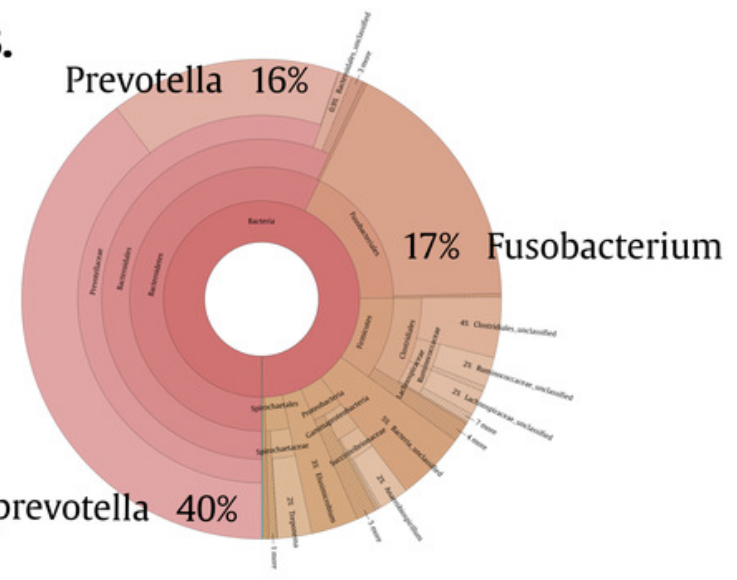

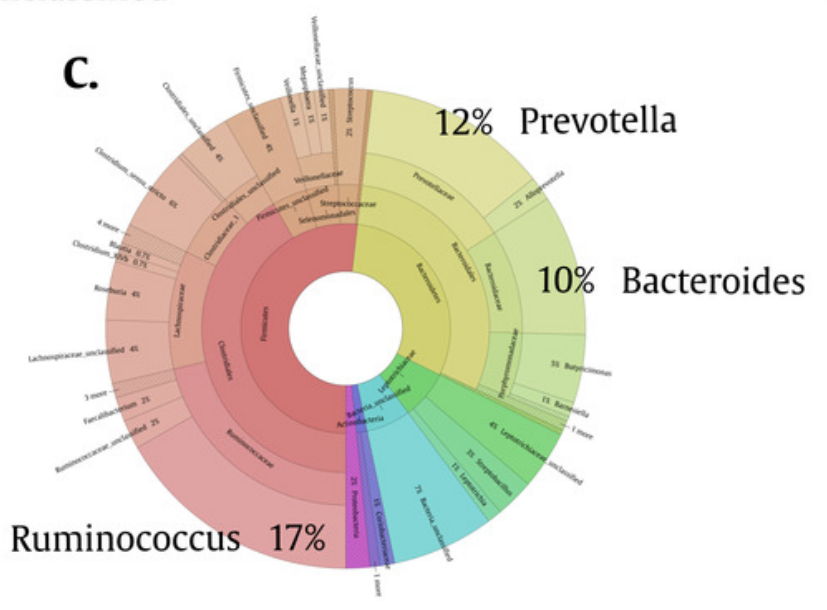

